\title{
Transcriptome and Function of Novel Immunosuppressive Autoreactive Invariant Natural Killer T Cells That Are Absent in Progressive Multiple Sclerosis
}

Belinda Carrión, MD, PhD, Yawei Liu, MD, PhD, Mahdieh Hadi, PhD, Jon Lundstrom, MSc, Jeppe Romme Christensen, MD, PhD, Cecilie Ammitzbøll, MD, PhD, Morten Hanefeld Dziegiel, MD, PhD, Per Soelberg Sørensen, MD, Manuel Comabella, MD, PhD, Xavier Montalban, MD, PhD, Finn Sellebjerg, MD, PhD, and Shohreh Issazadeh-Navikas, PhD

Neurol Neuroimmunol Neuroinflamm 2021;8:e1065. doi:10.1212/NXI.0000000000001065
Correspondence

Dr. Issazadeh-Navikas shohreh.issazadeh@bric.ku.dk

\section{Abstract}

\section{Background and Objective}

The aim of this study was to determine whether natural killer $\mathrm{T}$ (NKT) cells, including invariant (i) NKT cells, have clinical value in preventing the progression of multiple sclerosis (MS) by examining the mechanisms by which a distinct self-peptide induces a novel, protective invariant natural killer T cell (iNKT cell) subset.

\section{Methods}

We performed a transcriptomic and functional analysis of iNKT cells that were reactive to a human collagen type II self-peptide, hCII707-721, measuring differentially induced genes, cytokines, and suppressive capacity.

\section{Results}

We report the first transcriptomic profile of human conventional vs novel hCII707721-reactive iNKT cells. We determined that hCII707-721 induces protective iNKT cells that are found in the blood of healthy individuals but not progressive patients with MS (PMS). By transcriptomic analysis, we observed that hCII707-721 promotes their development and proliferation, favoring the splicing of full-length AKT serine/threonine kinase 1 (AKT1) and effector function of this unique lineage by upregulating tumor necrosis factor (TNF)-related genes. Furthermore, hCII707-721-reactive iNKT cells did not upregulate interferon (IFN)- $\gamma$, interleukin (IL)-4, IL-10, IL-13, or IL-17 by RNA-seq or at the protein level, unlike the response to the glycolipid alpha-galactosylceramide. hCII707-721-reactive iNKT cells increased TNF $\alpha$ only at the protein level and suppressed autologous-activated $\mathrm{T}$ cells through FAS-FAS ligand (FAS-FASL) and TNF $\alpha$-TNF receptor I signaling but not TNF receptor II.

\section{Discussion}

Based on their immunomodulatory properties, NKT cells have a potential value in the treatment of autoimmune diseases, such as MS. These significant findings suggest that endogenous peptide ligands can be used to expand iNKT cells, without causing a cytokine storm, constituting a potential immunotherapy for autoimmune conditions, including PMS.

\footnotetext{
From the Biotech Research and Innovation Centre (BRIC) (B.C., Y.L., M.H., J.L., S.I.-N.), University of Copenhagen; Danish Multiple Sclerosis Center (J.R.C., C.A., P.S.S.), University of Copenhagen and Department of Neurology, Rigshospitalet; Blood Bank (M.H.D.), Copenhagen University Hospital, Denmark; Centre d'Esclerosi Múltiple de Catalunya (M.C.), Cemcat, Unitat de Neuroimmunologia Clínica, Hospital Universitari Vall d'Hebron (HUVH) - Universitat Autònoma de Barcelona, Barcelona, Spain; and Centre d'Esclerosi Múltiple de Catalunya (X.M.), Cemcat, Unitat de Neuroimmunologia Clínica, Hospital Universitari Vall d’Hebron (HUVH) - Universitat Autònoma de Barcelona, Spain; Danish Multiple Sclerosis Center, University of Copenhagen and Department of Neurology, Rigshospitalet, Denmark.

Go to Neurology.org/NN for full disclosures. Funding information is provided at the end of the article.

The Article Procesing Charge was funded by Lundbeck Foundation; Danish Multiple Sclerosis Society, Independent Research Fund Denmark-Medical and Health Sciences (DFF-M), and Foundation for Research in Neurology to SI-N. Belinda Carrion received a PhD fellowship from CONACYT-Mexico and the Lundbeck. 


\section{Glossary}

AKT1 $=$ AKT serine $/$ threonine kinase $1 ;$ cDMEM $=$ complete Dulbecco's Modified Eagle Medium; CFSE $=$ carboxyfluorescein succinimidyl ester; convT = conventional CD4+ T cells; DMEM = Dulbecco's Modified Eagle Medium; DN = double-negative; EAE = experimental autoimmune encephalomyelitis; FACS = fluorescence-activated cell sorting; FAS-FASL $=$ FAS-FAS ligand; FDR = false discovery rate; GSEA = gene set enrichment analysis; $\mathbf{H C}=$ healthy control; $\mathbf{H D}=$ healthy donor; IFN = interferon; IL = interleukin; iNKT cell = invariant natural killer T cell; $\mathbf{M S}=$ multiple sclerosis; $\mathbf{N K T}=$ natural killer $\mathrm{T}$ cell; PMS = progressive MS, including PPMS and SPMS; PBMC = peripheral blood mononuclear cell; PPMS = primary progressive MS; RRMS = relapsing-remitting MS; SPMS = secondary progressive MS; TNF = tumor necrosis factor; TNFRI = TNF receptor I; TNFRII $=$ TNF receptor II; $\boldsymbol{\alpha}$-Galcer $=$ alpha-galactosylceramide; 7AAD $=$ 7-aminoactinomycin D.

Natural killer T (NKT) cells recognize lipid and glycolipid antigens on the major histocompatibility complex Class I-related CD1d. ${ }^{1-5}$ In addition to their host defense ${ }^{6}$ and antitumor activities, ${ }^{7}$ NKT cells are linked to the prevention of inflammation in allergic and autoimmune diseases. ${ }^{8-10}$ Multiple sclerosis (MS) is a chronic neuroinflammatory disease that is believed to be mediated by autoreactive lymphocytes, implicating a defect in NKT cells. ${ }^{11,12}$ Invariant iNKT (iNKT) cell levels are lower in the peripheral blood of patients with $\mathrm{MS},{ }^{13,14}$ and untreated patients with MS have more Th2-skewed iNKT cells during remission. ${ }^{15}$ iNKT cells can be induced by the glycolipid alpha-galactosylceramide ( $\alpha$-GalCer) to modulate experimental autoimmune encephalomyelitis (EAE), a model of MS, through Th2 cytokines. ${ }^{16,17}$ However, $\alpha$-GalCer treatment for EAE in mice causes liver toxicity, ${ }^{18}$ induces abortions, ${ }^{19}$ and exacerbates atherogenesis ${ }^{20}$ - possibly from a cytokine storm. Consistent with this model, on induction with $\alpha$-GalCer, NKT cells secrete high levels of IFN- $\gamma$ and IL-4, which can be harmful in MS. ${ }^{11}$ Thus, NKT cell responses to antigen must be discerned to develop NKT cell-based therapeutics. We have found that self-antigenic peptide-reactive NKT cells maintain peripheral tolerance, demonstrating that an immunodominant epitope from mouse collagen type II (mCII707-721) induces NKT cells, in turn inhibiting arthritis, neuroinflammation, and lung inflammation in models of rheumatoid arthritis, MS, and allergic asthma, respectively. ${ }^{21}$

We report a novel self-peptide-reactive NKT cell population in human peripheral blood. On being challenged with hCII707-721, they are activated and immunosuppressive in healthy individuals but hyporesponsive in patients with MS. Furthermore, we present the first transcriptional profile of human iNKTs, based on the effects of hCII707-721.

\section{Methods}

\section{Peripheral Blood Samples}

Peripheral blood was collected by standard venipuncture into vacuum tubes with ethylenediaminetetraacetic acid. Peripheral blood mononuclear cells (PBMCs) were isolated by Ficollisopaque density gradient centrifugation (Gibco-BRL). Peripheral blood from untreated relapsing-remitting MS (RRMS) and progressive MS (PMS) (primary progressive MS [PPMS] and secondary progressive MS [SPMS]) patients, classified per Lublin and Reingold, ${ }^{48}$ was obtained from the Danish Multiple Sclerosis Center and Multiple Sclerosis Center of Catalonia; blood from healthy donors (HDs) was acquired from Rigshospitalet, Denmark.

\section{Standard Protocol Approvals, Registrations, and Patient Consents}

The study was approved by the Scientific Ethics Committee for Copenhagen and Frederiksberg (protocol KF01-041/95) and the Hospital Universitari Vall d'Hebron Ethics Committee $[\mathrm{PR}(\mathrm{AG}) 32 / 2008]$ and was conducted after individual consent was obtained.

\section{Patients and Healthy Individuals}

In this cross-sectional study, in total, 146 subjects were included: 44 age- and gender-matched healthy controls (HCs), 26 patients with RRMS, 34 patients with PPMS, and 42 patients with SPMS. eTable 6 (links.lww.com/NXI/A555) details all the individuals' information included age, EDSS score, and disease duration.

Baseline $\mathrm{CD}^{-}$and $\mathrm{CD}^{-}$double-negative (DN) NKT cells were studied in patients with MS and HCs who had been recruited to the Danish MS Center, comprising HC: 24 women (mean age 37 years; range 24-62) and 8 men (39 years; 24-63), patients with RRMS: 14 women (38 years; $21-55$ ) and 5 men (34 years; $28-41$ ), PPMS: 8 women (51 years; $43-59$ ) and 12 men (47 years; 28-59), and SPMS: 11 women (46 years; $33-60)$ and 9 men (46 years; $30-53$ ).

Baseline iNKT cells were analyzed in patients with MS and HDs from the Danish MS Center; the blood bank at Rigshospitalet, Denmark; and Universitari Vall d'Hebron, Spain. The study population comprised HD: 9 women (44 years; 26-58) and 3 men ( 30 years; 23-37), patients with RRMS: 4 women ( 30 years; $24-37$ ) and 2 men ( 38 years; $36-41$ years), PPMS: 6 women (55 years; 52-60) and 6 men (51 years; 31-62), and SPMS: 7 women (54 years; 53-64) and 8 men (50 years; $36-62$ ).

The responsiveness to hCII707-721 was tested in vitro in freshly isolated human PBMCs from patients with PMS from the Danish MS Center and HDs. The 39 PBMC samples comprised 12 HDs, 12 PPMS, and 15 SPMS-HDs: 9 women 
Table 1 Demography of Individual Subjects Included in the Study

\begin{tabular}{|c|c|c|c|c|}
\hline Flow cytometry study & $\begin{array}{l}\text { Healthy } \\
\text { subject or MS }\end{array}$ & $\begin{array}{l}\text { Gender and } \\
\text { number of } \\
\text { samples }\end{array}$ & $\begin{array}{l}\text { Mean and } \\
\text { range in } \\
\text { years }\end{array}$ & Clinic \\
\hline \multirow[t]{8}{*}{ Baseline DN NKT } & $\mathrm{HC}$ & Female $n=24$ & $37(24-62)$ & Danish MS Clinic \\
\hline & & Male $n=8$ & $39(24-63)$ & Danish MS Clinic \\
\hline & RRMS & Female $n=14$ & $38(21-55)$ & Danish MS Clinic \\
\hline & & Male $n=5$ & $34(28-41)$ & Danish MS Clinic \\
\hline & PPMS & Female $n=8$ & $51(43-59)$ & Danish MS Clinic \\
\hline & & Male $n=12$ & $47(28-59)$ & Danish MS Clinic \\
\hline & SPMS & Female $n=11$ & $46(33-60)$ & Danish MS Clinic \\
\hline & & Male $n=9$ & $46(30-53)$ & Danish MS Clinic \\
\hline \multirow[t]{8}{*}{ Baseline iNKT } & $\mathrm{HD}$ & Female $\mathrm{n}=9$ & $44(26-58)$ & Blood Bank \\
\hline & & Male $n=3$ & $30(23-37)$ & Blood Bank \\
\hline & RRMS & Female $n=4$ & $30(24-37)$ & Universitari Vall d'Hebron MS Clinic \\
\hline & & Male $n=2$ & $38(36,41)$ & Universitari Vall d'Hebron MS clinic \\
\hline & PPMS & Female $n=6$ & $55(52-60)$ & Danish MS Clinic \\
\hline & & Male $n=6$ & $51(31-62)$ & Danish MS Clinic \\
\hline & SPMS & Female $n=7$ & $54(53-64)$ & Danish MS Clinic \\
\hline & & Male $n=8$ & $50(36-62)$ & Danish MS Clinic \\
\hline \multirow{6}{*}{$\begin{array}{l}\text { In vitro hClI707-721 } \\
\text { Reactivity }\end{array}$} & $\mathrm{HD}$ & Female $\mathrm{n}=9$ & $44(26-58)$ & Blood Bank \\
\hline & & Male $n=3$ & $30(23-37)$ & Blood Bank \\
\hline & PPMS & Female $n=6$ & $55(52-60)$ & Danish MS Clinic \\
\hline & & Male $n=6$ & $51(31-62)$ & Danish MS Clinic \\
\hline & SPMS & Female $\mathrm{n}=8$ & $54(36-64)$ & Danish MS Clinic \\
\hline & & Male $n=7$ & $50(36-62)$ & Danish MS Clinic \\
\hline \multirow{2}{*}{$\begin{array}{l}\text { iNKT } \\
\text { Suppressive assay and phenotyping }\end{array}$} & $\mathrm{HD}$ & Female $n=13$ & $33(19-57)$ & Blood bank \\
\hline & & Male $n=11$ & $42(21-59)$ & Blood bank \\
\hline RNA-seq & $\mathrm{HD}$ & Female $\mathrm{n}=3$ & $30-40$ & Blood bank \\
\hline
\end{tabular}

Abbreviations: $\mathrm{DN}=$ double-negative; $\mathrm{HC}=$ healthy control; $\mathrm{HD}=$ healthy donor; $\mathrm{iNKT}=$ invariant NKT; $\mathrm{MS}=$ multiple sclerosis; NKT = natural killer; PPMS = primary progressive MS; RRMS = relapsing-remitting MS; SPMS = secondary progressive MS.

(44 years; $26-58$ ) and 3 men (30 years; $23-37$ years), PPMS: 6 women (55 years; $52-60)$ and 6 men (51 years; $31-62)$, and SPMS: 8 women (54 years; $36-64)$ and 7 men (50 years; 36-62).

In vitro phenotyping and suppression of iNKT cells were analyzed in 24 HDs: 13 women (33 years; 19-57) and 11 men (42 years; $21-59$ ). Table 1 details the patients and $\mathrm{HC}$ included in the various assays.

None of the patients have received immunosuppressive or immunomodulatory treatment before sample date.
Preparation and Treatment of Human PBMCs

Buffy coats of blood donors and blood $(15 \mathrm{~mL})$ from patients with MS (10-12 mL) were used to prepare PBMCs using the Ficoll-Paque Plus (7.5 mL) (GE Healthcare, 17-1440-02). The cells were then centrifuged at $400 \mathrm{~g}$ for $30-40$ minutes at $18^{\circ} \mathrm{C}-20^{\circ} \mathrm{C}$. The lymphocyte layer was collected, washed 3 times with PBS, and centrifuged at $300 \mathrm{~g}$ for 10 minutes. The cells were resuspended at $3 \times 10^{6}$ cells $/ \mathrm{mL}$ in Dulbecco's Modified Eagle Medium (DMEM) with Glutamax-1 (Gibco), $10 \%$ fetal bovine serum (Sigma), 1\% HEPES $1 \mathrm{M}$ (Invitrogen), $1 \%$ penicillin-streptomycin 10,000 U/mL (Gibco), and $0.001 \%$ beta-mercaptoethanol $50 \mathrm{mM}$ to make complete DMEM 
(cDMEM). PBMCs were analyzed or stored in liquid nitrogen until use.

\section{Human Collagen II Peptide 707-721-Activated NKT Cells}

PBMCs were cultured in round-bottomed 96-well culture plates (Nunc) in a humidified $37^{\circ} \mathrm{C}$ atmosphere, containing $5 \% \mathrm{CO}_{2}$. PBMCs were treated with $5 \mu \mathrm{g} / \mathrm{mL} \alpha$-GalCer (KRN7000 Funakoshi Co, Ltd.), $100 \mu \mathrm{g} / \mathrm{mL}$ hCII707-721 (HPPGSNGNPGPPGPPG-OH Schafer-N), or collagen type I 707-721 as a negative control. Cells were stained with antibodies after 48 hours for a fluorescence-activated cell sorting (FACS) analysis.

\section{FACS Staining}

PBMCs were washed with PBS and 0.5\% BSA (Sigma). Fc receptors $(\mathrm{FcR})$ were blocked with antihuman $\mathrm{FcR}$ blocking reagent (Miltenyi Biotec 130-059-901) in PBS and 2\% BSA for 30 minutes at $4^{\circ} \mathrm{C}$ per the manufacturer's instructions. All antibodies were used at $1-5 \mu \mathrm{g} / \mathrm{mL}$ : TCR $\alpha \beta$ anti-human Pacific Blue (IP26 306716 Biolegend), CD4 antihuman APCCy7 (RPA-T4 300518 Biolegend), CD8 antihuman BV510 (RPA-T8 563526 BD Biosciences), CD56 antihuman BV605 (HCD56 318334 Biolegend), CD161 antihuman FITC (191B8 130-092-097 Miltenyi Biotec), CD94 antihuman APC (HP-3D9 17-5094 eBioscience) or Va24Ja18 TCR antihuman APC (6B11 17-5806 eBioscience), CD178 (FasL) antihuman PE (NOK-1 306407 Biolegend), CD3 antihuman APC- Cy7 (HIT3a 300318 Biolegend), CD4 PeCy7 antihuman (RPA-T4 300512 Biolegend), CD8 antihuman eFluorNC 605 (RPA-T8 94-0088 eBioscience), CD56 antihuman PerCP-Cy5.5 (HCD56 318322 Biolegend), and CD161 antihuman APC (DX12 V1NK12 BD Biosciences). 7-Aminoactinomycin D (7AAD) (BD Pharmingen 559925) was applied to exclude dead cells.

Intracellular cytokine staining was performed in iNKT magnetic bead-enriched PBMCs after blockade with Brefeldin-A $10 \mu \mathrm{g} / \mathrm{mL}$ (420601 Biolegend) for 6 hours, using IL-4 antihuman PE (8D4-8 500704 Biolegend), IFN- $\gamma$ antihuman Alexa Fluor-700 (4S.B3 502520 Biolegend), TNFa antihuman Alexa Fluor-488 (Mab11 55,722 BD Pharmingen), IL17F antihuman PerCP efluor- 710 (SHLR17 46-7169 eBioscience), granzyme B antihuman/mouse FITC (GB11 515403 Biolegend), perforin antihuman APC (DG9 308111 Biolegend), and TGF- $\beta 1$ antihuman PE-Cy7 (TW4-2F8 349610 Biolegend).

Cells were acquired on a BD LSR II using FACSDiva and analyzed in FlowJo (Tree), v8.8.7.

\section{Purification of iNKT Cells}

PBMCs $\left(4-10 \times 10^{8}\right)$ were cultured in CDMEM at $3 \times 10^{6}$ cells $/ \mathrm{mL}$ with hCII707-721 $(100 \mu \mathrm{g} / \mathrm{mL})$ in T- $175 \mathrm{~cm}^{2}$ flasks (Nunc/Fischer). After activation with hCII707-721 for 48 hours, total iNKT cells were purified by autoMACS using Anti-iNKT MicroBeads (130-094-842, Miltenyi Biotec). To distinguish the hCII707-721-treated iNKT cells before purifcation from nontreated iNKT cells, the hCII707-721-treated iNKT cell population is referred to as hCII707-721-reactive iNKT cells.

\section{CFSE Staining}

PBMCs were labeled with fresh $1 \mu \mathrm{M}$ carboxyfluorescein succinimidyl ester (CFSE; Molecular Probes) at $37^{\circ} \mathrm{C}$ for 2 minutes and then at room temperature for 7 minutes in the dark. An equal volume of fetal bovine serum was added to halt the reaction, and the cells were washed 3 times with cDMEM.

\section{In Vitro Suppression Assay}

PBMCs were labeled with CFSE and activated $\left(2 \times 10^{5}\right.$ cells/ well) with plate-bound anti-CD3 $10 \mu \mathrm{g} / \mathrm{mL}$ (OKT3 16-003781 eBioscience) and human soluble anti-CD28 $2 \mu \mathrm{g} / \mathrm{mL}$ (CD28.2 16-028981 eBioscience) for 48 hours. Autologous hCII707721-reactive iNKT cells from the same HD were purified by autoMACS and cocultured at 1:1 with $\mathrm{CFSE}^{+}$PBMCs for another 24 hours.

For certain experiments, 1 hour before coculture, PBMCs were blocked with antibodies against human Fas $(250 \mathrm{ng} / \mathrm{mL}$, ZB4 Millipore 05-338), TNF receptor I (TNFRI) (10 $\mu \mathrm{g} /$ $\mathrm{mL}, \mathrm{H} 398$ In vivo Gen mab-htnfr1), and TNF receptor II (TNFRII) $(0.5 \mu \mathrm{g} / \mathrm{mL}, 22221 \mathrm{R} \& \mathrm{D}$ Systems MAB226). IgG (BD Pharmingen Purified Mouse IgG/IgG2a $\kappa$ Isotype 564121/554126) was used as a negative control.

After 24 hours of coculture, cells were harvested and supplemented with $7 \mathrm{ADD}$ before FACS analysis of $\mathrm{CFSE}^{+}$vs $7 \mathrm{AAD}^{+}$cells.

\section{ELISA}

Supernatants from in vitro PBMC cultures, treated with $\alpha$-GalCer and hCII707-721 for 48 hours, were analyzed using the Granzyme B Platinum ELISA kit (Affymetrix eBioscience BMS2027) per the manufacturer's instructions.

\section{RNA-Seq Sample Preparation and Gene Expression Analysis}

Total RNA was extracted from PBMCs samples (3 women HDs, 30-40 years) using the RNeasy mini kit (Qiagen, $74,104)$. The RNA-seq samples were composed of 3 biological individual samples for each population, that is, 3 conventional $\mathrm{T}$ cells, 3 conventional iNKT cells (without hCII707-721 activation), and 3 hCII707-721-reactive iNKT cells (with hCII707-721 activation). Messenger ribonucleic acid was prepared using oligo-dT primers and reverse transcribed (KAPA Biosystems, KK2601). The double-stranded DNA was tagmented (Illumina, FC-131-1096) and ligated with sequencing adaptors (Illumina, FC-131-2002) as detailed. ${ }^{49}$

Libraries were pooled (1.6 pM) and sequenced through paired-end 75-bp reads on an Illumina NextSeq500. Three biological replicates were used for RNA-seq for each condition (3 healthy women, 30-40 years). Quality control and 
preprocessing steps were performed using FastQC and Trimmomatic. Gene expression was quantified by mapping the reads to the human genome (GRCh38.p13, GENCODE v32) using Salmon (v0.14.1). On average, there were $10.5 \mathrm{M}$ mapped reads per library. Pairwise comparison of biological replicates between conditions was performed using edgeR. Differential isoform usage was analyzed using IsoformSwitchAnalyzeR ${ }^{50}$ Pathway and gene ontology enrichment analysis was performed in R using ReactomePA, ${ }^{51}$ CAMERA, ${ }^{52}$ and fgsea. ${ }^{53-55}$ For the pathway enrichment analysis, we used annotated gene sets from the Molecular Signatures Database. ${ }^{54}$

\section{Data Availability}

All data generated or analyzed during this study are included in this published article (and its supplementary information files).

\section{Results}

\section{Reduced Circulating NKT Cells and a Lack of hCll707-721-Reactive iNKT Cells in PMS}

Patients with PMS are often older than patients with RRMS, and because age could be a confounding factor affecting immune cells, we investigated first if age affects the frequency of NKT cells. The correlation analysis of age vs subset frequency in the HCs did not reveal a significant impact of the age interval used in the study on the frequency of NKT cells (eFigure 1, links.lww.com/NXI/A547).

In examining whether PMS is associated with NKT subsets using established markers, we did not find any differences in single positive $\mathrm{CD}^{+}{ }^{+}$or $\mathrm{CD} 4^{+} \mathrm{NKT}$ cells between MS and HCs, nor did we find differences based on $\mathrm{CD}_{56} 6^{+}, \mathrm{CD}^{+} 5^{+}$, and $\mathrm{CD} 161^{+}$triple-positive population (data not shown). However, in support of previous studies, ${ }^{13,14}$ among double-negative cells $\left(\mathrm{CD} 4^{-} \mathrm{CD} 8^{-} \mathrm{DN}^{22}\right)$, the percentages of $\mathrm{CD} 4^{-} \mathrm{CD} 8^{-} \mathrm{CD} 161^{+}$ $\mathrm{NKT}$ cells and $\mathrm{CD} 4^{-} \mathrm{CD} 8^{-} \mathrm{CD} 56^{+} \mathrm{CD} 161^{+} \mathrm{NKT}$ cells were lower in patients with PPMS (Figure 1A-C). Based on the invariant TCR $\alpha$-chain Va24Ja18 (Figure 1D), we found a decrease in iNKT cells, albeit insignificant, in both PMS patient groups but not RRMS patients (Figure 1E).

Healthy individuals harbored no hCII707-721-reactive $\mathrm{CD} 4^{+}$or DN NKT cells after a 48-hour challenge with this peptide (not shown) but had a significant population of a novel hCII707721-reactive iNKT subset (Figure 1F,G). Gating on Va24Ja18 iNKT cells (Figure 1F), hCII707-721, not $\alpha$-GalCer, significantly increased the percentage of iNKTs in HDs (Figure 1G). Furthermore, patients with PMS, particularly those with SPMS, had fewer hCII707-721-reactive iNKT cells vs HDs (Figure 1G).

\section{Human iNKT-specific Transcriptomic Signature}

No complete gene signature of human iNKT cells has been reported. To address this shortcoming, we purified naïve conventional $\mathrm{CD} 4^{+} \mathrm{T}$ cells (convT), conventional iNKT cells, and hCII707-721-reactive iNKT cells from PBMCs and Va24Ja18expressing cells, respectively, and performed RNA sequencing. We considered all iNKTs as an entity, regardless of their activation status, based on their clustering in principal component analysis plots and gene expression profiles (false discovery rate $[\mathrm{FDR}]<0.05$ ) (Figure $2 \mathrm{~A}$ and eFigure $2 \mathrm{~A}$ and $\mathrm{B}$, links.lww. com/NXI/A548).

iNKT cells had a distinct transcriptional profile compared with convT cells, wherein 1927 genes were differentially expressed (FDR < 0.05) (Figure 2A-B, eTable 1, links.lww.com/NXI/ A550), 139 of which were lncRNAs (Figure 2C, eTable 2, links. lww.com/NXI/A551). Of these 1,927 genes, 1,397 were significantly upregulated and 530 were downregulated (Figure 2B, D). Next, we annotated cell surface markers and transcription factors $^{23}$ among these differential genes to identify the top surface markers and a transcription factor network that were related to iNKT function-constituting the gene signature of iNKTs (Figure 2E-F, eTable 1). The iNKT-specific transcription factor profile was used to perform STRING network analysis, ${ }^{24}$ in which overrepresented Reactome pathways were identified among the core factors (eFigure 2A-C, links.lww.com/NXI/ A548).

Next, we performed a Reactome pathway enrichment analysis of the upregulated genes to identify the molecular pathways that were associated with iNKT differentiation and function (Figure $2 \mathrm{G}$ ). The resulting pathways reflected the cytotoxic nature of iNKT cells and included terms that are associated with important effector functions, such as degranulation (neutrophil degranulation), ROS production (ROS and RNA production in phagocytes), and interleukin signaling (interleukins 4, 13, and 10). Finally, we conducted gene set enrichment analysis (GSEA) of the iNKT profile vs convT, confirming the upregulation of iNKT effector functions using several pathway databases (Figure 2H).

\section{Transcriptomic Profiling Reveals hCII707- 721-Induced Activation and Proliferation of iNKTs}

Compared with conventional nonactivated iNKT cells, hCII707-721-reactive iNKT cells upregulated 115 genes and downregulated 59 genes $(p<0.05,|\log \mathrm{FC}|>0.5)$ (Figure 3A-C, eFigure 2D, links.lww.com/NXI/A548, eTable 3, links.lww.com/NXI/A552), 33 of which were lncRNAs (Figure 3D, eTable 4, links.lww.com/NXI/ A553) - the first indication that hCII707-721 activates human iNKT cells.

By GSEA, genes in pathways that were related to iNKT effector function were consistently upregulated. In 3 databases (GO, KEGG, and Reactome), proliferation-related pathways were the most highly upregulated (Figure 3E). Furthermore, the appearance of hematopoietic cell lineage by KEGG (FDR $=0.096)$ suggested that lineage commitment and differentiation occurred on activation (Figure 3E-F). In addition, hCII707-721 enhanced the effector function of iNKTs, based on their upregulation of TNF-related genes (ReactomeTNFs bind their physiologic receptors, FDR $=0.054)$ (Figure 3E). 
A
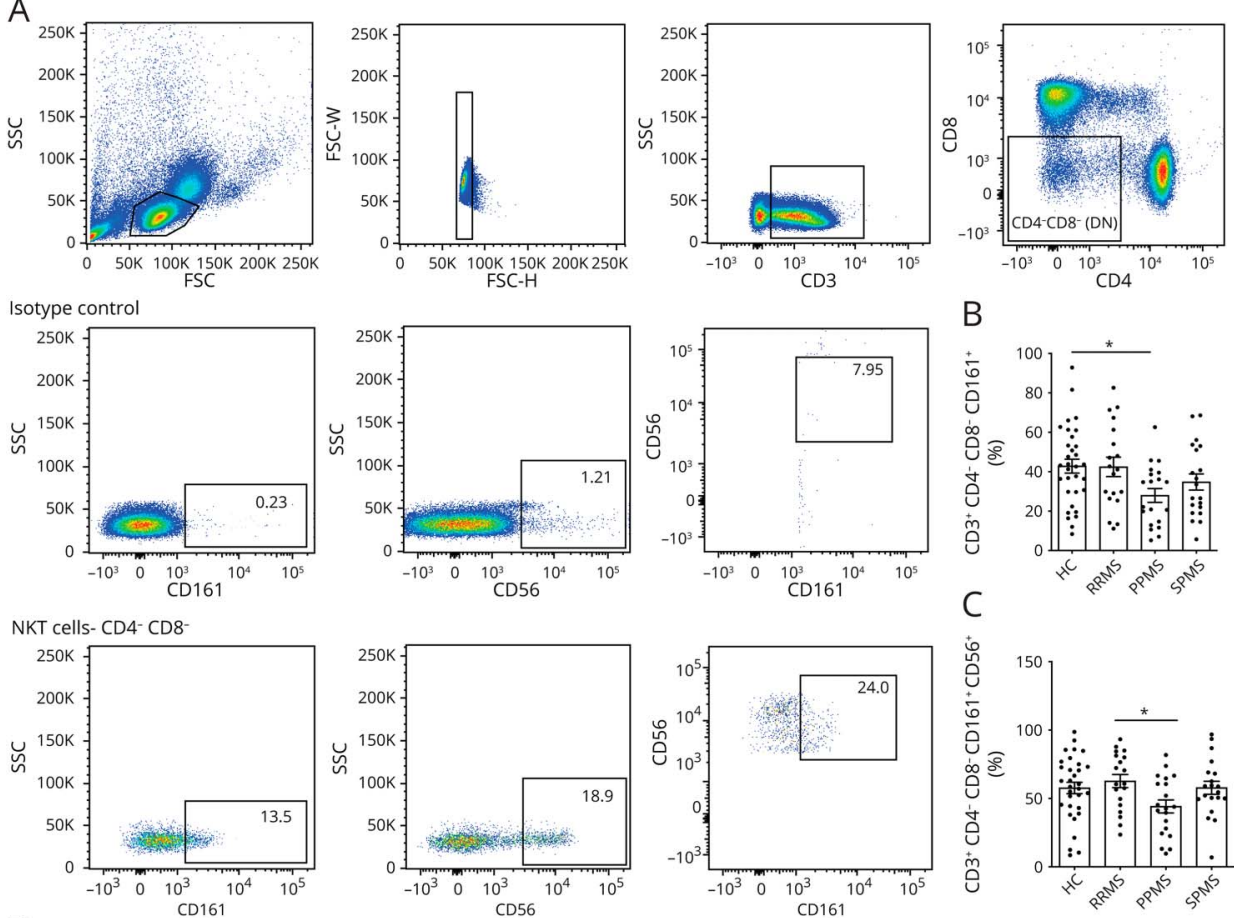

D
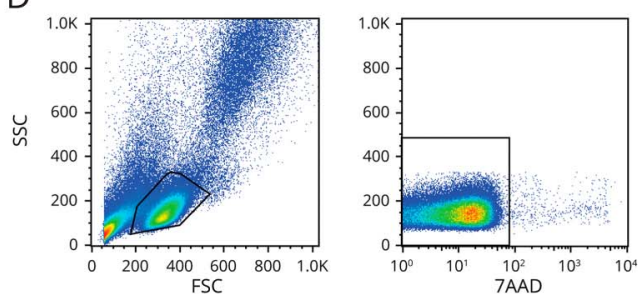

E

F.a Isotype control
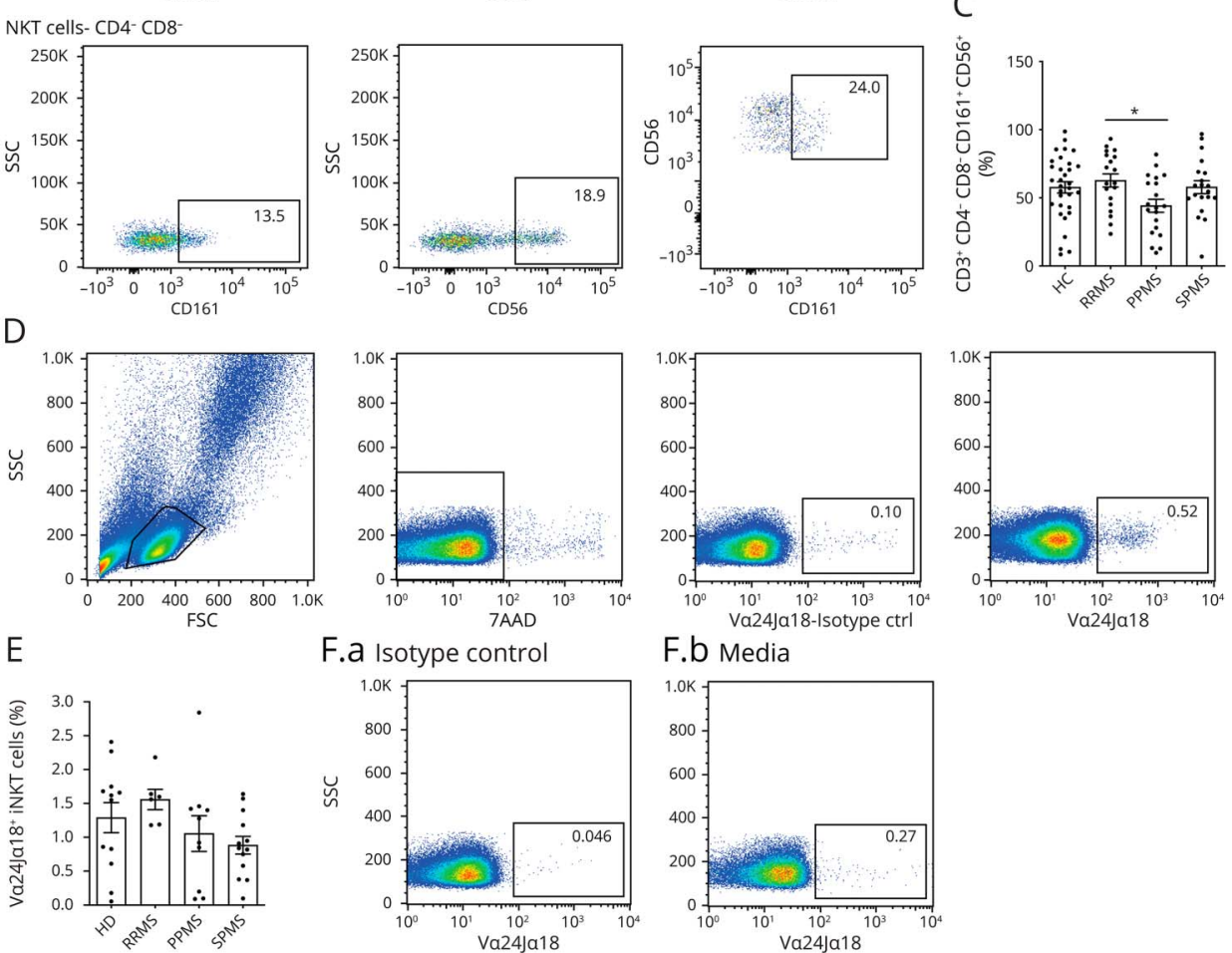

F.b Media
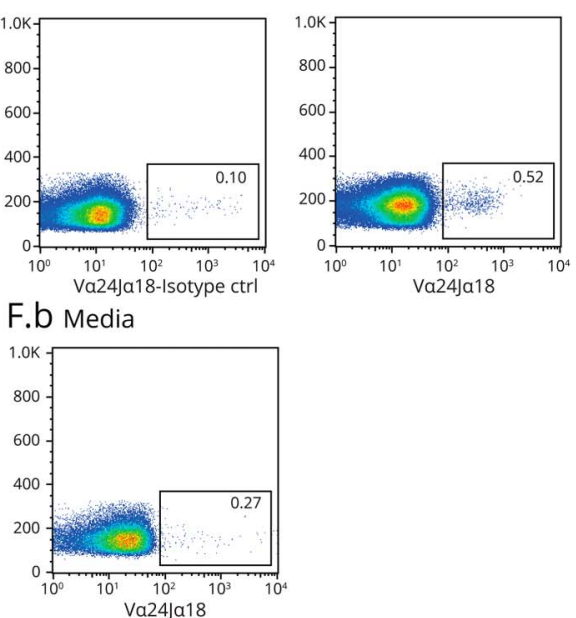

F.C aGalcer

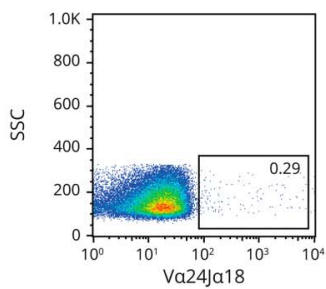

F.d hClI

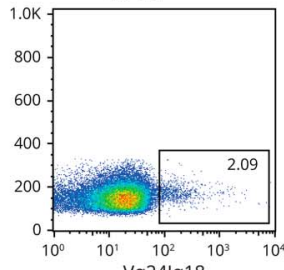

G

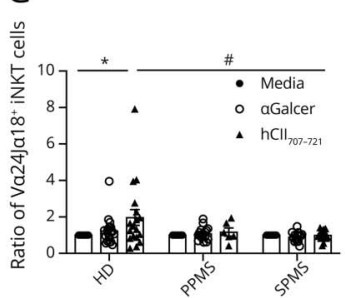

PBMCs were freshly isolated from each subject and stained with CD3, CD4, CD8, CD56, CD161, and Va24Ja18. (A) FACS gating strategy of CD3 ${ }^{+} C D 4{ }^{-} C D 8^{-}$(DN) NKT cells and gating of DN CD56 ${ }^{+} \mathrm{CD} 161^{+}$NKTs. (B) The percentage of DN NKT cells based on CD161 expression. (C) The percentage of DN NKT cells based on CD56 and CD161 expression. The bars indicate the mean \pm SEM in HC $(n=32)$, patients with RRMS $(n=19)$, patients with PPMS $(n=20)$, and patients with SPMS $(n=20)$, (D) Gating of Va24Ja18 ${ }^{+}$iNKT cells from single and live lymphocytes compared with isotype control-stained cells. (E) The percentage of Va24Ja18 ${ }^{+}$iNKT cells. The bars indicate the mean \pm SEM. HD $(n=12)$, RRMS $(n=6)$, PPMS $(n=10)$, and SPMS $(n=13)$. * $p<0.05$ One-way ANOVA with the Tukey multiple comparison test was

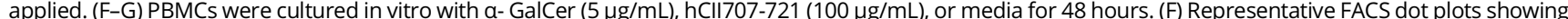
gating of Va24Ja1 $8^{+}$iNKT cells in the various treatments. (G) Ratio of Va24Ja1 $8^{+}$iNKT cells. The value of Va24ja1 $8^{+}$iNKT cells in nontreated sample (media) $=1$ for HD, PPMS, and SPMS (empty bar). Ratio is calculated as the percentage of treated Va24ja1 $8^{+}$iNKT cells/percentage of Va24Ja1 $8^{+}$iNKT cells in media. The bars indicate the mean \pm SEM, HD $(n=18)$, PPMS $(n=6-18)$, and SPMS $(n=15-18)$. Student $t$ test was applied * $p<0.05$ between control and hCII707-721 in HDs. \#p< 0.05 between $\mathrm{HD}$ and SPMS with hCII707-721 treatment. ANOVA = analysis of variance; $\mathrm{CD}=$ cluster of differentiation; $\mathrm{DN}=$ double-negative; $\mathrm{FACS}=$ fluorescenceactivated cell sorting; $\mathrm{HC}=$ healthy control; $\mathrm{HD}=$ healthy donor; $\mathrm{NKT}=$ natural killer T; $\mathrm{PBMC}=$ peripheral blood mononuclear cell; PPMS = primary progressive MS; RRMS = relapsing-remitting MS; SEM = standard error of mean; SPMS = secondary progressive MS. 


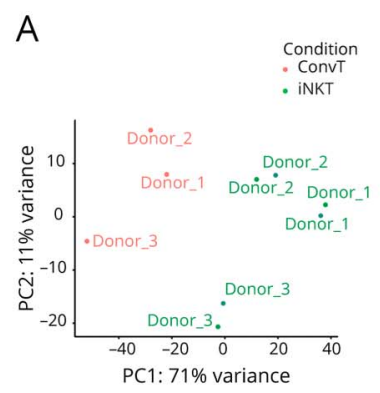

E. Cell surface

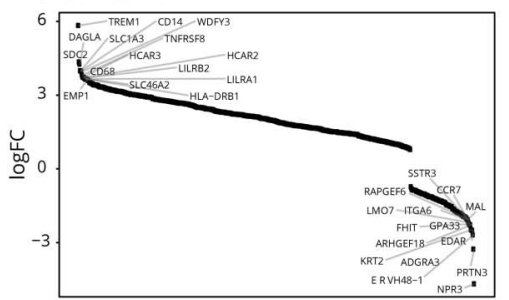

G

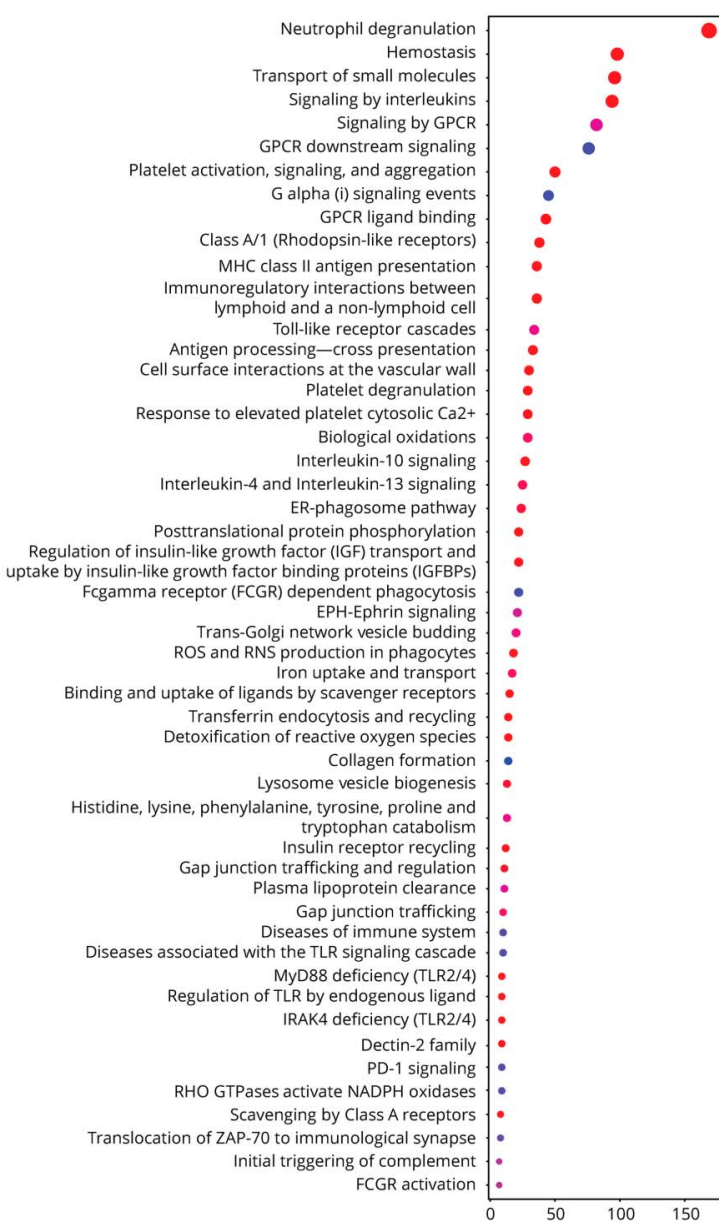

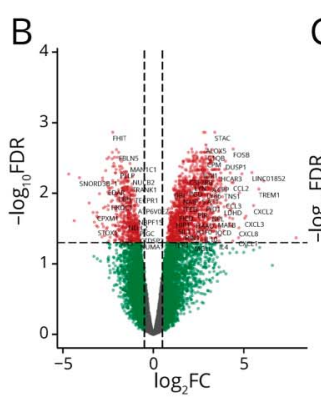

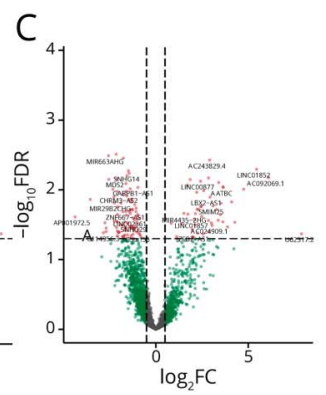

F. Transcription factor

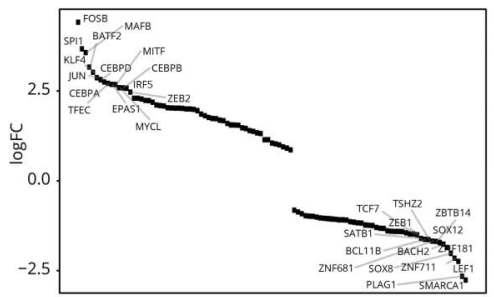

$\mathrm{H}$

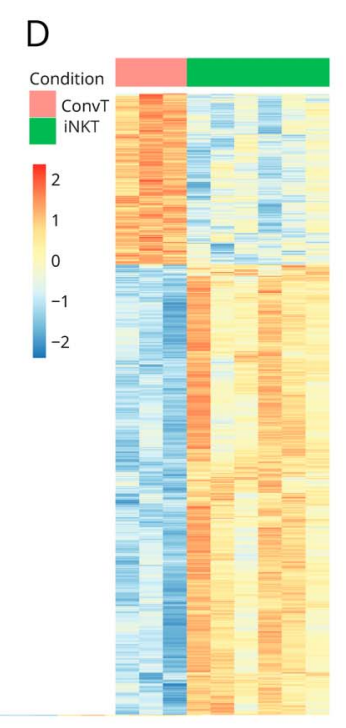

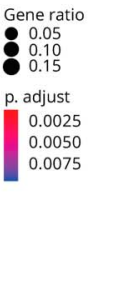
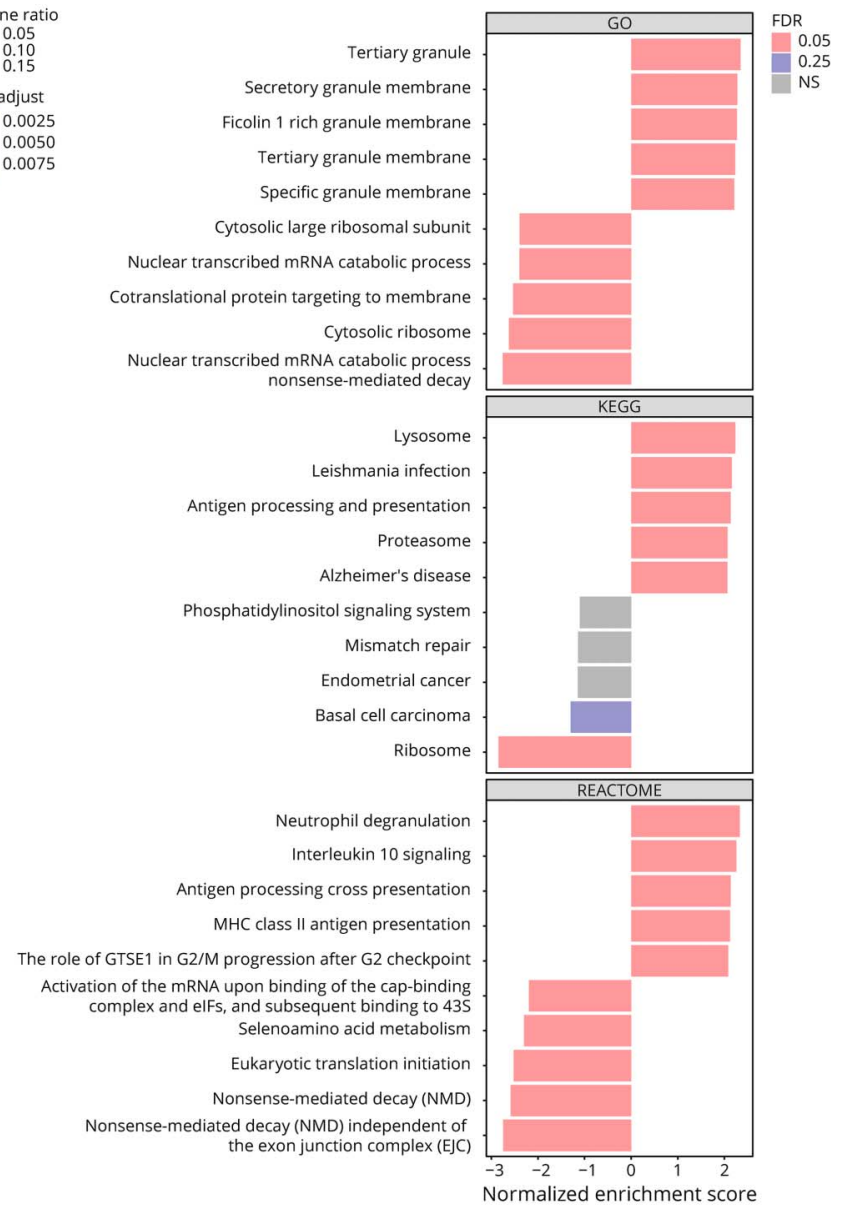

Conventional T cells, conventional iNKT cells (without hCII707-721 activation), and hCII707-721-reactive iNKT cells (with hCII707-721 activation) purified from PBMCs were analyzed by RNA-seq. Conventional iNKT cells and hCII707-721-reactive iNKT cells were considered as a single group as iNKT cells in this analysis. $\mathrm{n}=3$ /group. (A) Principal component analysis plot of convT (red) and iNKT cells (green). (B) Volcano plot of signature genes of iNKT cells vs conventional T cells (FDR < 0.05). (C) Volcano plot of differentially expressed IncRNAs between iNKT and conventional T cells (FDR < 0.05). (D) Heatmap of NKT signature genes. (E) A snake plot of cell surface markers of NKT cells highlighted the 15 upregulated and 15 downregulated genes. (F) A snake plot of transcription factor markers of NKT cells highlighted the 15 upregulated and 15 downregulated genes. (G) Top 50 enriched Reactome pathways among the genes that are upregulated in NKT cells vs convT. (H) GSEA showing the enriched pathways and molecular functions in iNKT cells per the GO, KEGG, and Reactome databases. convT = conventional CD4+ T cells; FDR = false discovery rate; GSEA = gene set enrichment analysis; iNKT = invariant NKT; NKT = natural killer T cell; PBMC = peripheral blood mononuclear cell. 


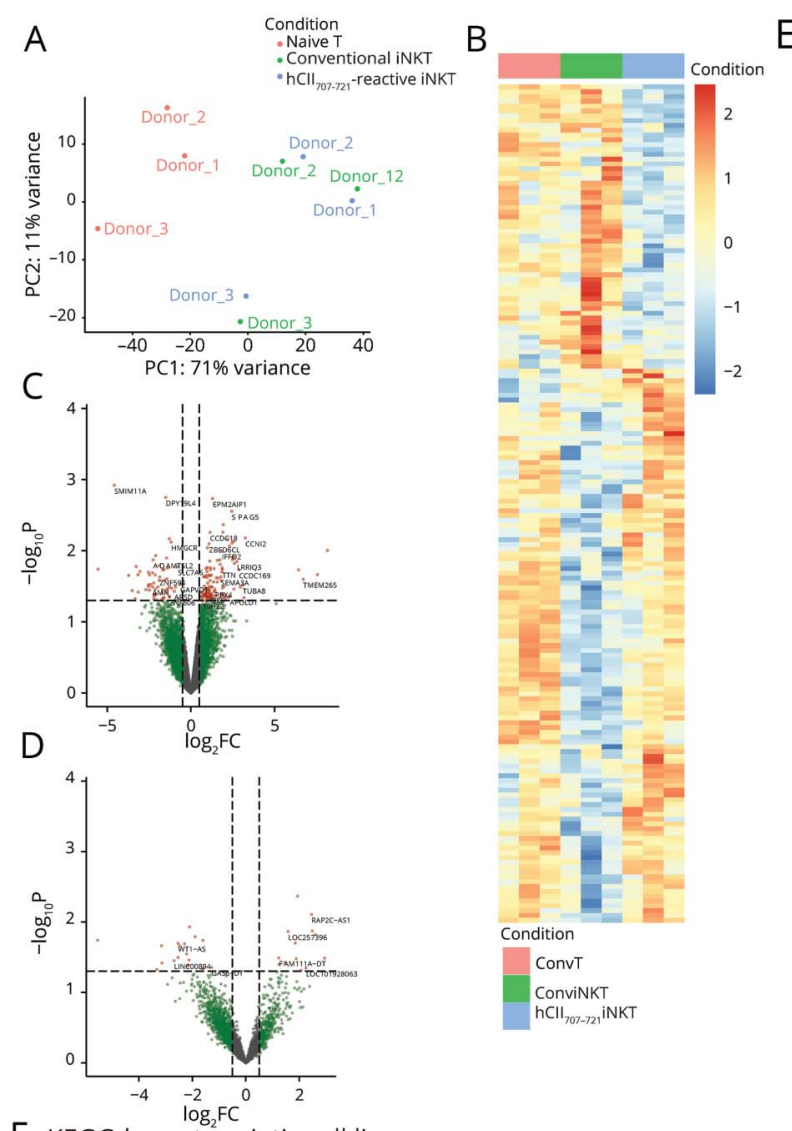

F. KEGG-hematopoietic cell lineage

EDR
$<0.05$
$<0.25$
NS

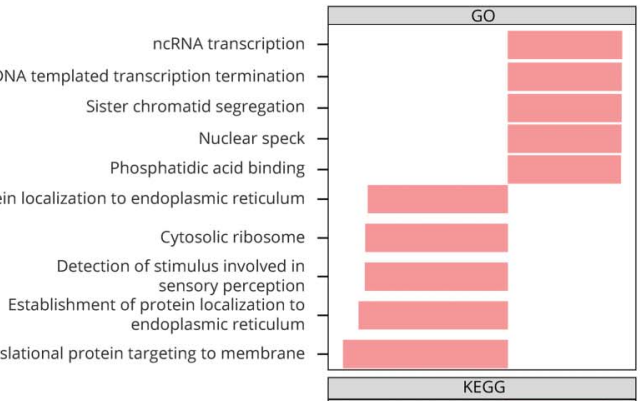

$\left.\begin{array}{r}\text { Nuclear speck } \\ \text { Phosphatidic acid binding } \\ \text { Protein localization to endoplasmic reticulum } \\ \text { Cytosolic ribosome } \\ \text { Detection of stimulus involved in } \\ \text { sensory perception } \\ \text { Establishment of protein localization to } \\ \text { endoplasmic reticulum }\end{array}\right]$

$$
\text { Protr }
$$
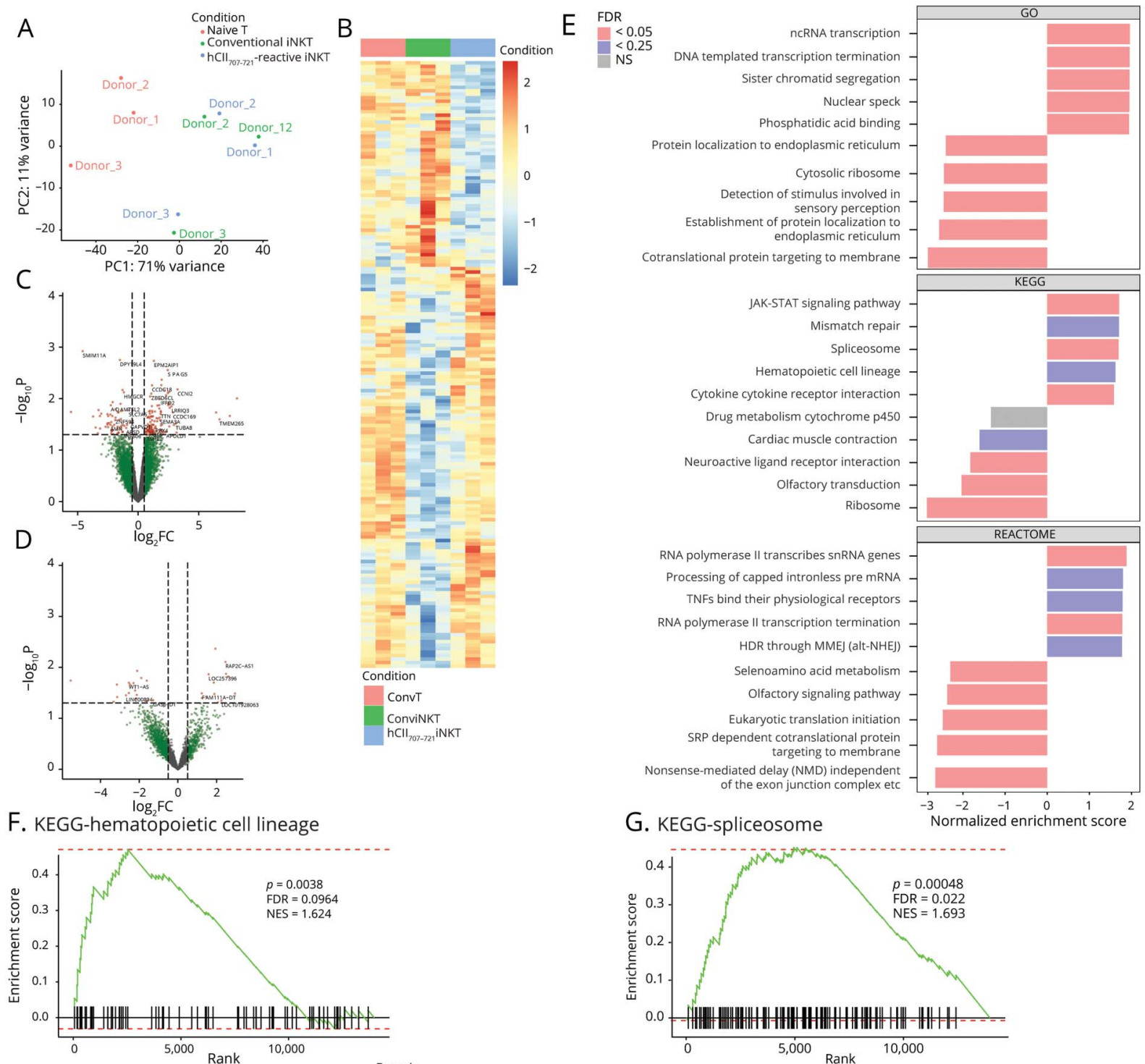

G. KEGG-spliceosome
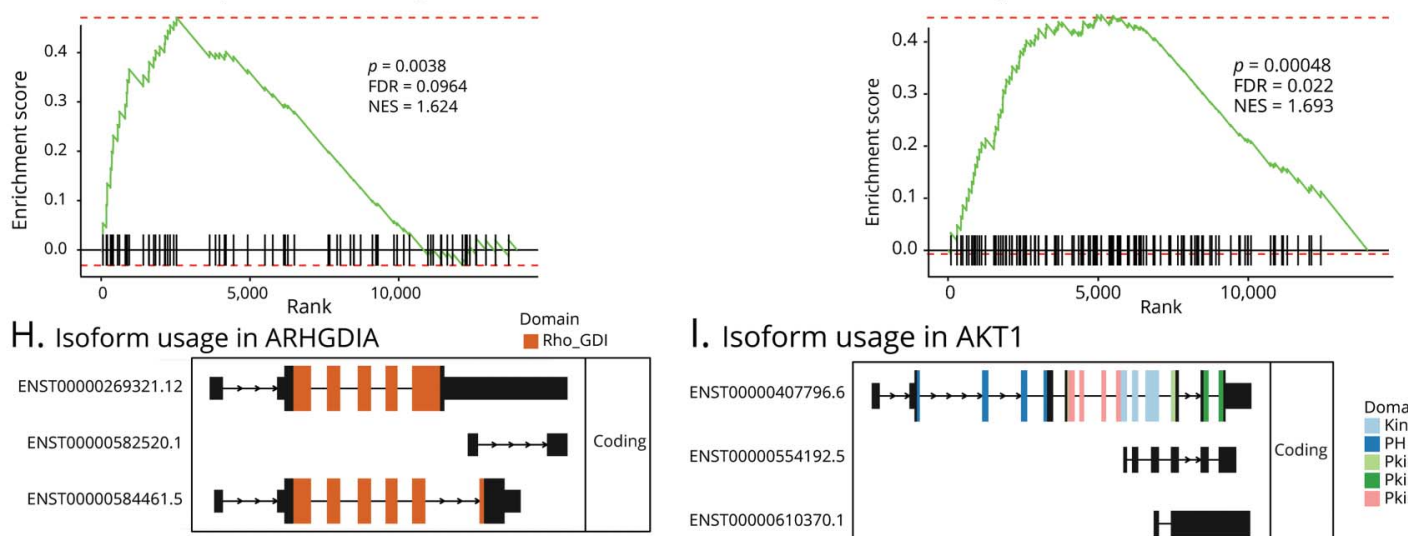

I. Isoform usage in AKT1

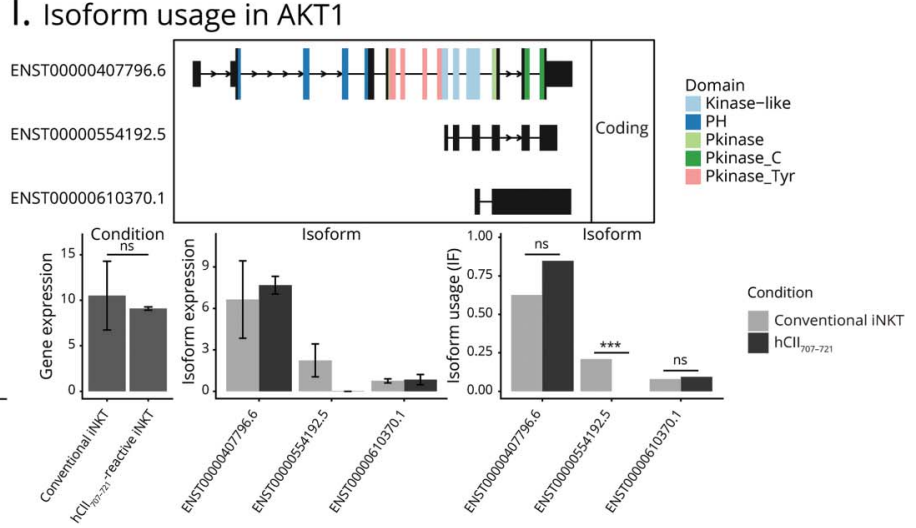

Treated iNKT cells were analyzed by RNA-seq compared with iNKT cells and convT. (A) Principal component analysis plot of conventional T cells, conventional iNKT cells, and hCII707-721-reactive iNKT cells. (B) Heatmap of differentially expressed genes in hCII707-721-reactive iNKT compared with iNKT. (C) Volcano plot showing the signature genes of $\mathrm{hCII707-721-reactive} \mathrm{iNKT} \mathrm{vs} \mathrm{untreated} \mathrm{iNKT} \mathrm{cells}(p<0.05)$. (D) Volcano plot showing the IncRNAs differentially expressed between hCII707-721-reactive iNKT and conventional iNKT $(p<0.05)$. (E) GSEA of regulated GO, KEGG, and Reactome pathways in hCII707-721-reactive iNKT vs conventional iNKT cells. (F) Enrichment plot of KEGG-Hematopoietic cell lineage pathway in hCII707-721-reactive iNKT vs conventional iNKT cells $(p=$ $0.0038, \mathrm{FDR}=0.0964, \mathrm{NES}=1.624)$. (G) Enrichment plot of KEGG-Spliceosome pathway in hCll707-721-reactive iNKT vs conventional iNKT cells $(p=0.00048$ $\mathrm{FDR}=0.022$, NES $=1.693$ ). (H) Differential isoform use of ARHGDIA in hCII707-721-reactive iNKT cells. (I) Differential isoform use of AKT1 in hCII707721-reactive iNKT cells. FDR = false discovery rate; GSEA = gene set enrichment analysis; iNKT = invariant NKT; NES = normalized enrichment scores. 
Given the upregulation of the KEGG_SPLICEOSOME pathway $(F D R=0.022)$ (Figure $3 G)$, we examined whether alternative splicing was induced by hCII707-721, finding 67 genes with significant differential isoform usage (eFigure $3 \mathrm{~A}$ and B, links.lww.com/NXI/A549, eTable 5, links.lww.com/ NXI/A554). Specifically, on stimulation, Rho GDP dissociation inhibitor alpha (ARHGDIA) changed to a nonfunctional isoform that lacked the functional domain, promoting Rho GTPase activation, which mediates $\mathrm{T}$ cell activation, ROS production, and cell migration ${ }^{25,26}$ (Figure 3H). Furthermore, hCII707-721 favored splicing of full-length AKT serine/threonine kinase 1 (AKT1), which mediates cell growth and proliferation ${ }^{27}$ (Figure 3I).

\section{Cytokine and Cytotoxic Molecule Profile of hCII707-721-Reactive iNKT Cells}

Given that cytokine pathways were among the top KEGG pathways in hCII707-721-reactive iNKT cells (Figure 3D), we examined NKT cell signature cytokines in our RNA-seq data set. None of these cytokines was upregulated on stimulation with hCII707-721 (Figure 4A). The RNA-seq data were verified by intracellular cytokine measurements, merely showing significantly higher TNF $\alpha$ in hCII707-721-reactive iNKT cells vs conventional iNKT cells (gated on Va24Ja18 ${ }^{+}$ cells) (Figure 4B-F). By ELISA, IFN- $\gamma$, IL-4, and IL-17F levels were minor (data not shown). Notably, unlike the reported massive induction of cytokines on administration of $\alpha$-GalCer, ${ }^{28}$ we found that hCII707-721 does not alter the expression or production of intracellular IFN- $\gamma$, TGF- $\beta$, or IL17F (Figure 4B).

Perforin and granzyme B were expressed in nonactivated conventional iNKT cells (Figure 4G), consistent with previous reports. ${ }^{29,30}$ In addition, perforin expression did not differ between hCII707-721-reactive and nonactivated conventional iNKT cells (Figure 4G-I, M). Notably, granzyme B expression and secretion were reduced in hCII707-721-reactive iNKT cells vs conventional iNKT cells (Figure 4G, H, J, L, N). hCII707721-reactive iNKT cells also produced significantly less granzyme B than $\alpha$-GalCer-reactive iNKT cells (Figure 4L). FasL was upregulated on activation of iNKT cells with hCII707-721 compared with nonactivated iNKT cells, albeit insignificantly (Figure 4G-H, K, O).

\section{hCII707-721-Reactive iNKT Cells Suppress Activated T Cells Through Fas/FasL and TNFa/ TNFRI}

As shown in Figure 5A-D, by in vitro suppression assay, the proliferation of activated responder $T$ cells declined significantly in the presence of enriched autologous hCII707-721-reactive iNKT cells, without significantly affecting cell death (by 7AAD ${ }^{+}$ staining) (Figure 5E-F), such as murine CII707-721-reactive NKT cells, ${ }^{21}$ whereas nonactivated conventional iNKT cells effected no significant suppression (Figure 5G-K).

By transcriptomic analysis, hCII707-721-reactive iNKT cells upregulated Fas and TNF signaling (Figure $5 \mathrm{~L}$ and $\mathrm{M}$ ). Thus, we hypothesized that hCII707-721-reactive iNKT cells suppress by engaging the Fas- FasL pathway. Suppression assay, using a blocking antibody to Fas on activated $\mathrm{T}$ cells, revealed the importance of this pathway (Figure $5 \mathrm{~N}-\mathrm{O}$ ). Because hCII707-721-reactive iNKT cells have higher TNF levels and because cytotoxic lymphocytes induce cell death through TNF/TNFR, ${ }^{31}$ we also blocked TNFRI and TNFRII on activated $\mathrm{T}$ cells to determine the involvement of TNFRI in iNKT cell-mediated suppression (Figure $5 \mathrm{~N}-\mathrm{O}$ ). Although the secretion of other cytokines by NKT cells is important for their function, ${ }^{3,6,7,32}$ we did not find any indication of their association with reactivity to hCII707-721, consistent with the absence of cytokine-mediated suppression in murine CII707721-reactive NKT cells. ${ }^{21}$

Blocking Fas-FasL and TNFRI abolished the suppressive function of hCII707-721-reactive iNKT cells against activated $\mathrm{T}$ cell proliferation, whereas blocking TNFRII had no such effect (Figure $5 \mathrm{~N}-\mathrm{O}$ ). However, the percentage of cell death (7AAD staining) was not affected (data not shown). These data suggested that both Fas-FasL and TNF-TNFRI signaling are involved in hCII707-721-reactive iNKT cell-mediated suppression.

\section{Discussion}

The dysregulation of regulatory and suppressive immune cell types in autoimmune conditions ${ }^{33}$ has spawned efforts to identify new such populations, culminating in the description of murine CII707-721-reactive NKT cells ${ }^{21}$ and circulating FoxA1 ${ }^{+}$Treg cells in human blood. ${ }^{34}$ In response to self-antigens and foreign antigens, NKT cells activate rapidly and develop proinflammatory and immunoregulatory functions, resulting in protective or harmful responses in many pathologies in mice and humans, including autoimmune disease, allergy, and cancer. ${ }^{6,10,33,35,36}$ This association underscores the importance of understanding the function and regulation of NKT cells to exploit them in the management of these diseases. ${ }^{37}$

NKT cells have been implicated in MS, causing motor deficits, loss of coordination, cognitive and visual disturbances, and ultimately severe disability. ${ }^{11}$ In keeping with their immunoregulatory functions, lower levels of and functional defects in NKT cell subsets have been reported in patients with MS. ${ }^{13,14}$ Conclusively, previous studies on this topic have been contradictory, ${ }^{13-}$ 15,22 likely because different markers were used to study NKT cell subsets in MS. Consistent with the evidence of a lower percentage of circulating NKT cells, in this study, we noted a lower percentage of various NKT cell populations in patients with PMS, including DN-NKT and iNKT cells. These findings indicate that NKT cells are protective in MS and that their absence is associated with disease progression.

The major adverse effects of $\alpha$-GalCer render it a suboptimal option for treating MS, perpetuating the unmet clinical need for therapies that activate protective NKT cells. Given the therapeutic potential of NKT cells and our description of 


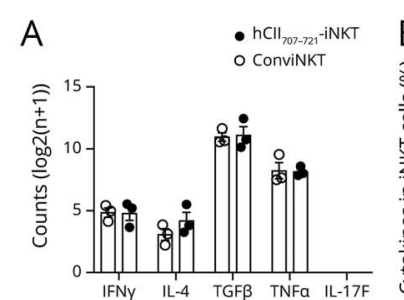

D. Isotype control
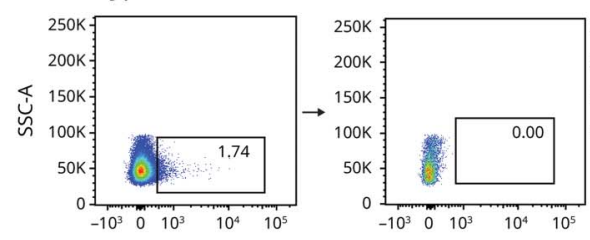

E. ConviNKT
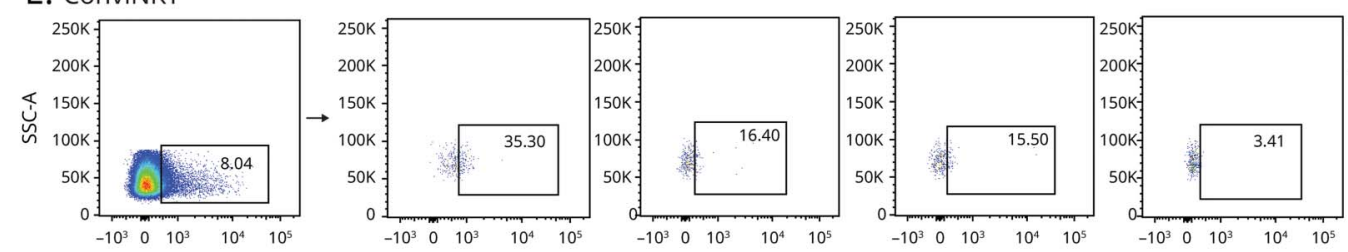

F. hCll ${ }_{707-721}-\mathrm{iNKT}$

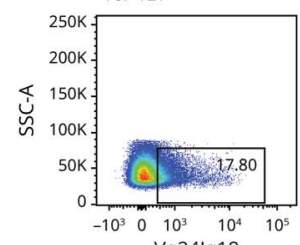

Va24Ja18

G. ConviNKT

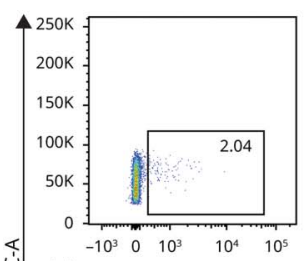

H. hCII

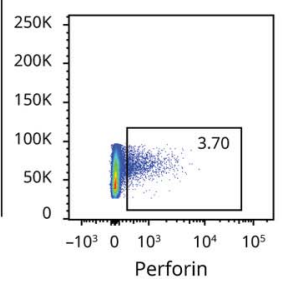

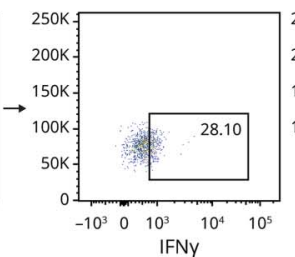

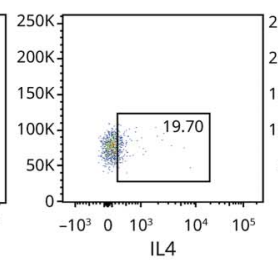

IL4
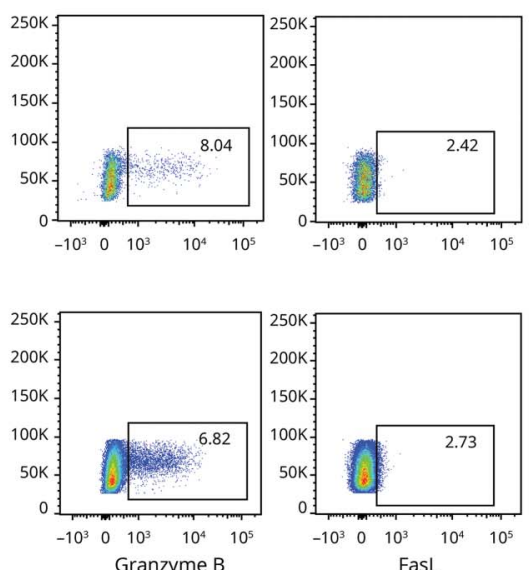

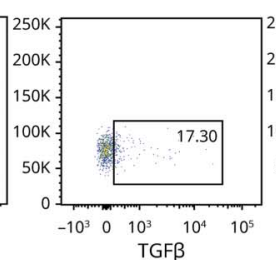

TGFB
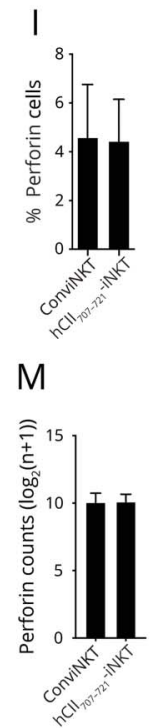
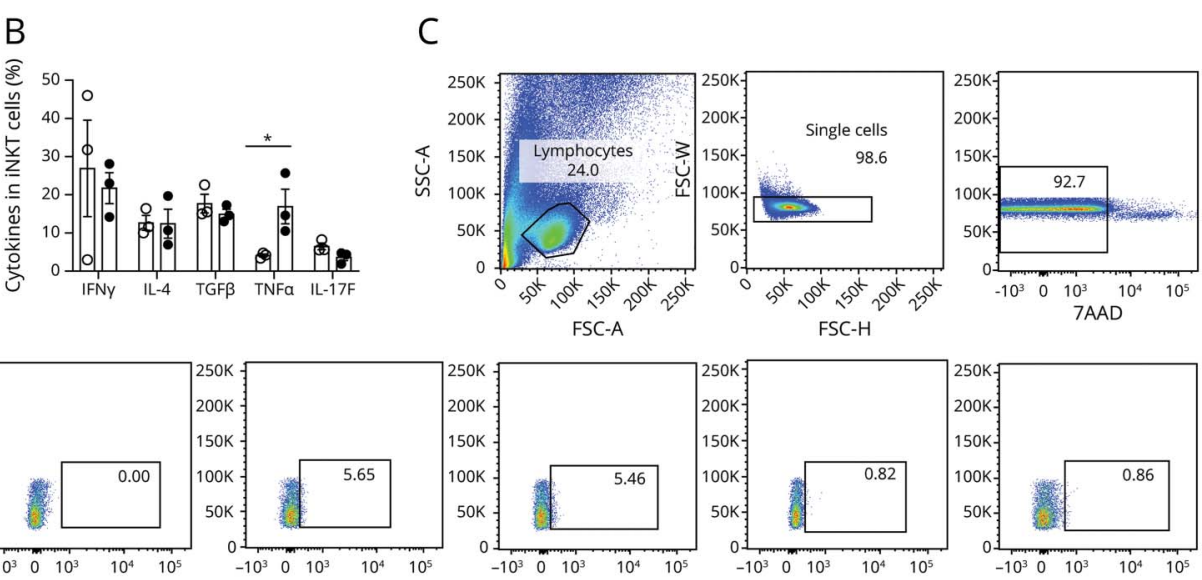

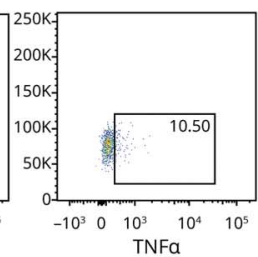

TNFa
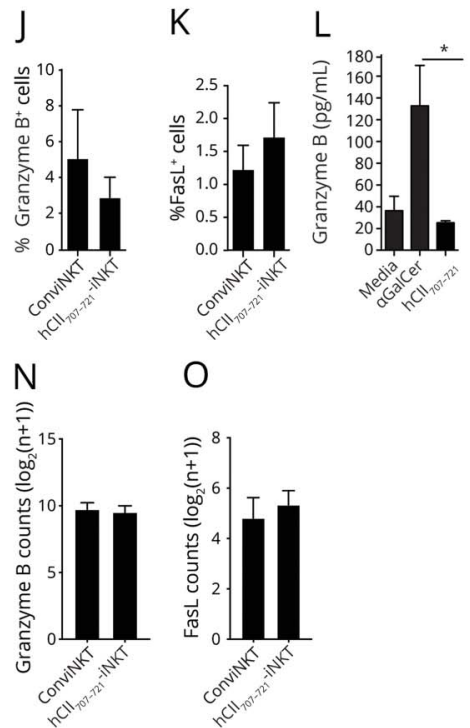

O

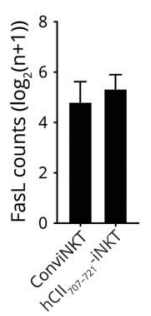

PBMCs were isolated from HDs and treated with or without hCII707-721 for 48 hours. Cells were gated for Va24Ja18 ${ }^{+}$iNKT cells. (A) Normalized counts (from RNA-

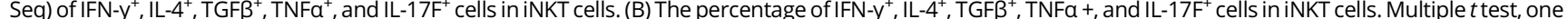
per row was applied. ${ }^{*} p<0.05$ between hCII707-721 and untreated conventional iNKTs in HDs. (C) Dot plots showing the back-gating strategy for lymphocyte population, single cells, and live cells. (D) Dot plots of isotype controls for various cytokine stains. (E) Representative dot plots of cytokine stains from untreated conventional iNKT cells. (F) Representative dot plots of cytokine stains from $\mathrm{hCll1707-721-reactive} \mathrm{iNKT} \mathrm{cells.} \mathrm{(G)} \mathrm{Representative} \mathrm{dot} \mathrm{plots} \mathrm{of} \mathrm{perforin}{ }^{+}$, granzyme $\mathrm{B}^{+}$, and Fas $\mathrm{L}^{+}$cells from gated nontreated conventional iNKT cells. (H) hCll107-721-reactive iNKT cells. (I) The percentage of perforin ${ }^{+}(\mathrm{l})$ and granzyme $\mathrm{B}^{+}$cells in gated iNKT cells. (K) FasL $\mathrm{L}^{+}$cells in gated iNKT cells. (L) Granzyme B production by-GalCer, hCII707-721, and untreated conventional iNKT cells after 48 hours of culture, (M) normalized counts (log2-transformed normalized counts from DESeq2) of perforin expression by RNA-seq. (N) Normalized counts of granzyme B expression by RNA-seq. (O) Normalized counts of FasL by RNA-seq. The bars indicate the mean \pm SEM; $n=3-4$. HD = healthy donor; IFN = interferon; IL = interleukin; NKT = natural killer T; PBMC = peripheral blood mononuclear cell; SEM = standard error of mean; TGF = transforming growth factor; TNF = tumor necrosis factor. 

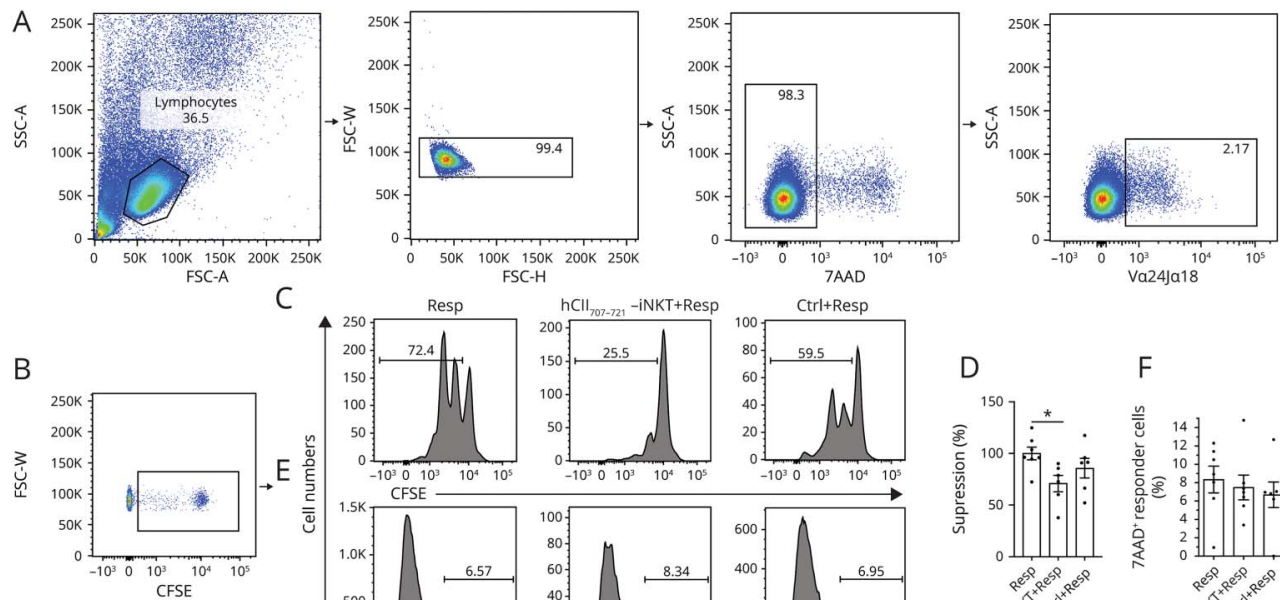

C FSC-H

Ctrl+Resp
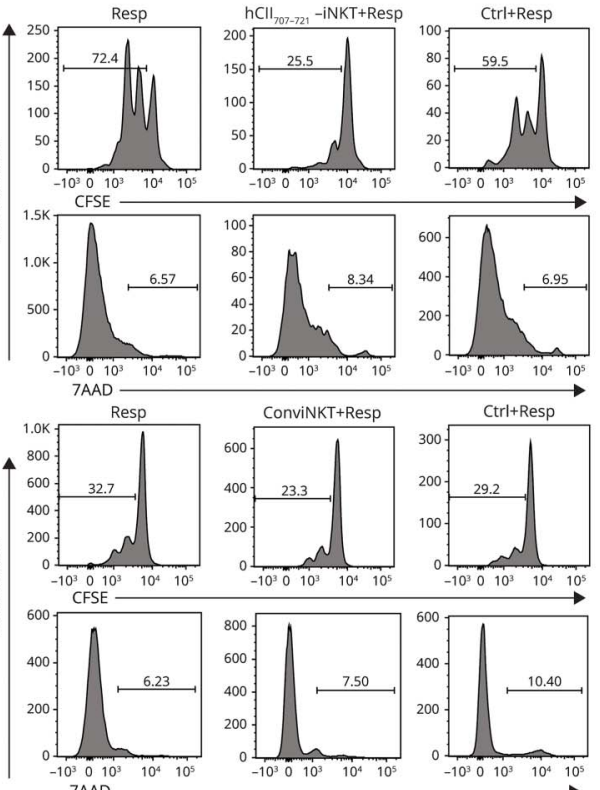

G

$\mathrm{H}$

L. PID-TNF pathway
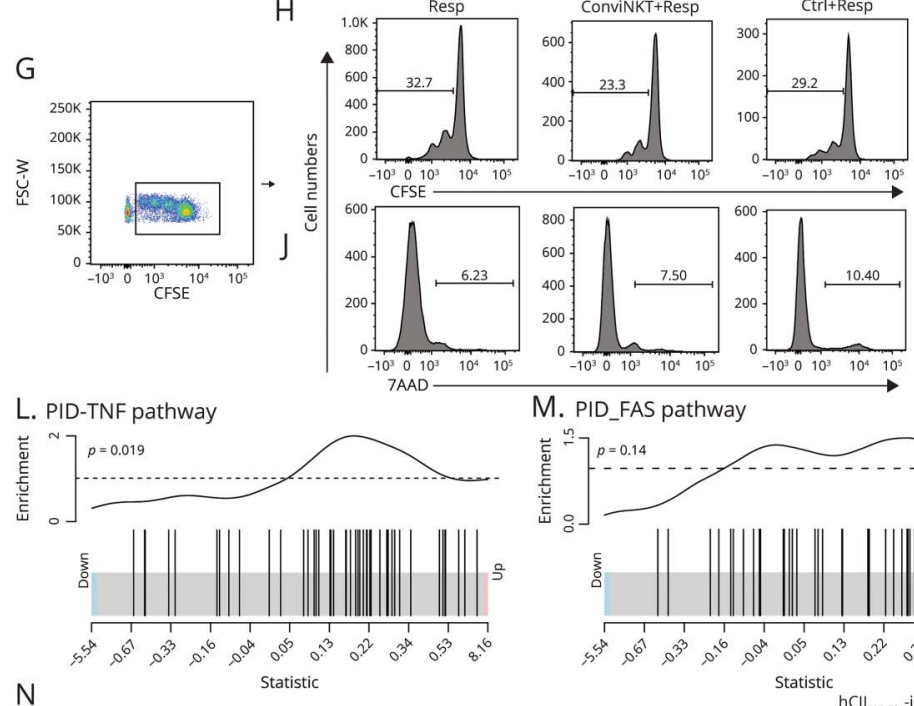

D

F
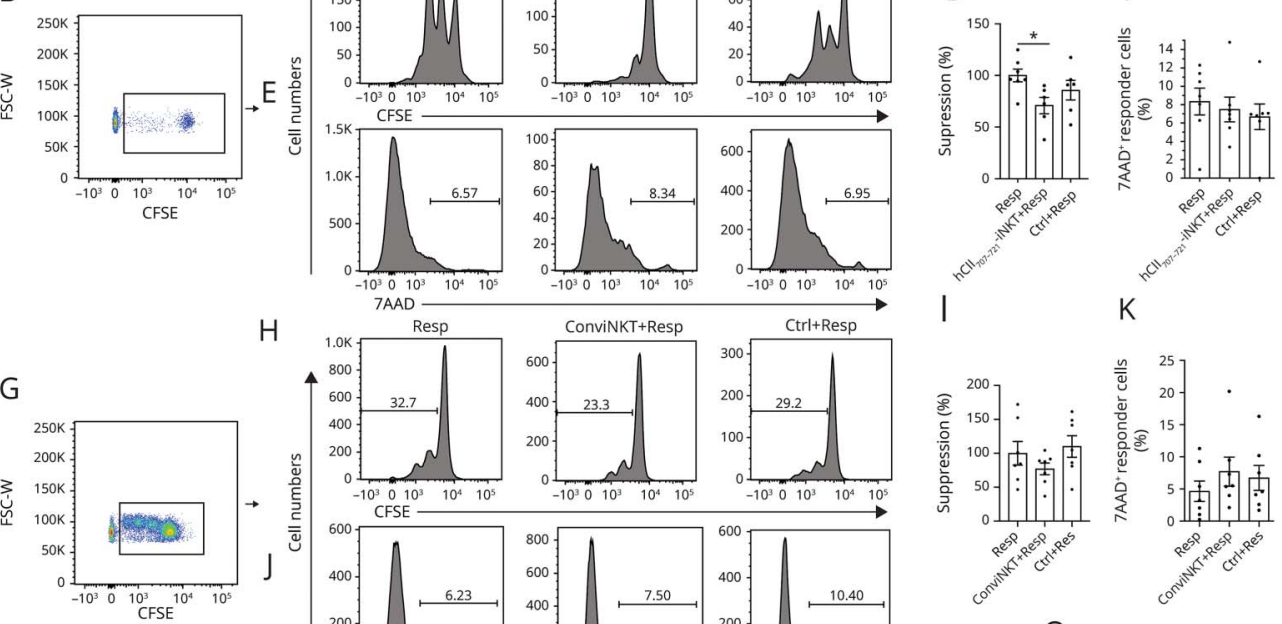

M. PID_FAS pathway
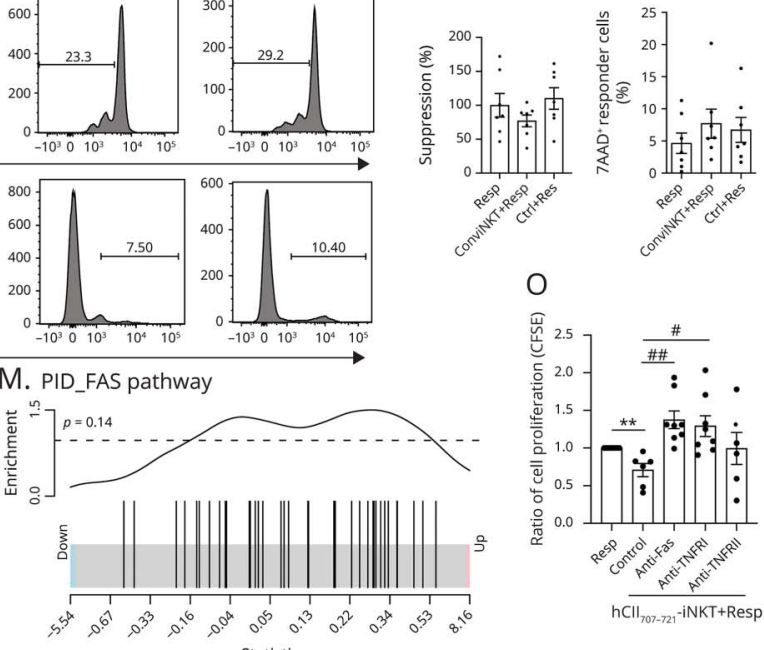

$\mathrm{N}$
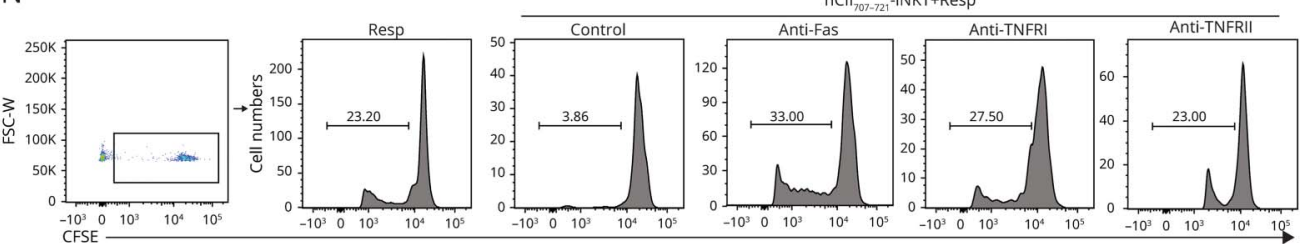

CFSE ${ }^{+}$PBMC cells from HDs were activated with plate-bound anti-CD3 $(10 \mu \mathrm{g} / \mathrm{mL})$ and soluble anti- CD28 $(2 \mu \mathrm{g} / \mathrm{mL})$ for 48 hours as responders (Resp) and cocultured with purified autologous hCII707-721-reactive Va24Ja18 ${ }^{+}$iNKT cells or control cells (Va24Ja18 cells) for another 24 hours. (A) FACS gating strategy of back-gating and gating for Va24Ja18 $8^{+}$iNKT cells. (B) FACS plot of gating strategy for responder CFSE + cells (hCll707-721-reactive Va24Ja18 ${ }^{+}$iNKT cells as suppressors). (C) hCII707721-reactive Va24Ja1 $8^{+}$iNKT cells from PBMCs of a HD were enriched with magnetic beads before coculture with autologous activated responder T lymphocytes for functional suppression assay. Va24Ja1 $8^{+}$iNKT cells were obtained by treatment with $\mathrm{hCll707-721}\left(100 \mu \mathrm{g} / \mathrm{mL}\right.$ ) for 48 hours (C-F) or from conventional Va24Ja18 ${ }^{+}$iNKT (G-K). (D) Representative histograms of CFSE ${ }^{+}$gating in Resp CFSE responder T cells (Resp) cocultured with reactive hCll707-721 Va24Ja18 ${ }^{+}$iNKT cells or control cells (Va24ja18 cells) for another 24 hours. (E) Representative histograms of 7AAD ${ }^{+}$gating in Resp cocultured with reactive hCll707- 721 Va24ja18 ${ }^{+}$iNKT cells or control cells (Va24Ja18 cells). (F) The percentage of 7AAD ${ }^{+}$dead cells in Resp CFSE ${ }^{+}$responder T cells (Resp) were then cocultured with reactive hCII707-721 Va24Ja18 ${ }^{+}$iNKT cells or control cells (Va24Ja18 cells) for another 24 hours. (G) FACS plot of gating strategy for responder CFSE+ cells (conventional Va24Ja18 ${ }^{+}$iNKT cells as suppressors). (H) Conventional Va24Ja18 ${ }^{+}$iNKT cells cocultured with autologous activated responder T lymphocytes for functional suppression assay. Representative histograms of CFSE $^{+}$gating in Resp CFSE ${ }^{+}$responder T cells (Resp) cocultured with conventional Va24Ja18 ${ }^{+}$iNKT cells or control cells (Va24ja18- cells) for another 24 hours, with percentages in (I). () Representative histograms of 7AAD gating in Resp cocultured with conventional Va24Ja18 ${ }^{+}$iNKT cells or control cells (Va24Ja18 cells). (K) The percentage of 7AAD dead cells in Resp CFSE ${ }^{+}$responder T cells (Resp) cocultured with conventional Va24Ja18 ${ }^{+}$iNKT cells or control cells (Va24Ja18 cells) for another 24 hours. One-way ANOVA * $p<0.05$. The bars indicate the mean \pm SEM, $n=7$. (L) TNF pathway (PID, MSidDB) enrichment in hCII707-721-reactive iNKT cells compared with conventional iNKT cells (FDR $=0.038$ ). (M) FAS pathway (PID, MSidDB) enrichment in hCII707-721-reactive iNKT vs conventional iNKT cells (FDR = 0.14). (N) Gating strategy for responder CFSE + cells and proliferating CFSE ${ }^{+}$cells. (O) The percentage of proliferating CFSE cells. Ratio of Resp-only (without neutralizing antibodies) set to 1; ratios calculated as percentage of proliferating CFSE cells in various cocultures/percentage of proliferating CFSE ${ }^{+}$cells in Resp-only. The bars indicate the mean \pm SEM; $\mathrm{n}=6$-8. Unpaired student $t$ test was applied; $* p<0.05$ between Resp + iNKT (Control) and Resp-only. One-way ANOVA and Dunnett multiple-comparisons test: $\# p<0.05$, $\# \# p<0.01$ between groups with blocking antibodies and control group. ANOVA = analysis of variance; CFSE = carboxyfluorescein succinimidyl ester; FACS = fluorescence-activated cell sorting; $\mathrm{FDR}$ = false discovery rate; $\mathrm{HD}$ = healthy donor; $\mathrm{MS}$ = multiple sclerosis; $\mathrm{NKT}$ = natural killer $\mathrm{T}$; $\mathrm{PBMC}=$ peripheral blood mononuclear cell; PID = The Pathway Interaction Database; SEM = standard error of mean; TNF = tumor necrosis factor; TNFRI = TNF receptor I; 7AAD = 7-Aminoactinomycin D. 
murine CII707-721-reactive NKT cells, ${ }^{21}$ we examined whether similar cells with possible clinical benefit existed in humans. This premise led to our identification of hCII707721 , revealing the existence of a novel iNKT cell population in healthy persons that is absent in patients with PMS and prompting us to characterize their molecular and suppressive properties. We have identified the first human self-peptide hCII707-721-reactive iNKT cell population in healthy humans and determined their transcriptional profile, which was borne out in their suppressive function.

Effector function pathways are significantly enriched in iNKT vs convT cells, including NK cell-mediated immunity, chemokine and cytokine responses, signal transduction, and cell motility and survival. ${ }^{38}$ In our study, some such activities were validated in the general human iNKT cell signature, and others appeared only on activation of iNKT cells with hCII707-721.

Previous studies on the suppressive functions of iNKT cells have focused on the involvement of cytokines, based on the ability of NKT cells to robustly and rapidly produce cytokines that drive Th1, Th2, and Th17 cell differentiation and function. 3,6,7,32 Although the "cytokine-cytokine receptors" interaction was among the major KEGG pathways that were induced by hCII707-721 in iNKT cells, the activation of iNKT cells by hCII707-721 was not associated with any specific cytokine pattern, except for higher TNFa levels. Consistent with this finding, our transcriptomic analysis of hCII707-721-reactive iNKT vs conviNKT cells implicated the TNF pathway as being significantly enriched. Although blocking TNFRII on activated $\mathrm{T}$ lymphocytes did not hinder the antiproliferative effects of hCII707-721-reactive iNKT cells, TNF $\alpha$-mediated TNFRI signaling - a pathway that induces cell death ${ }^{31}$ — contributed to their suppressive activity.

We found that the suppressive function of hCII707721-reactive iNKT cells was also mediated by Fas-FasL signaling, as observed for murine CII707-721-reactive NKT cells. ${ }^{21}$ A similar mechanism was reported in the killing of tumor cells by GalCer-activated NKT cells, ${ }^{39}$ consistent with the regulation of $\mathrm{T}$ cells by NKT cells through Fas/ FasL. ${ }^{40,41}$ As our study has shown, cooperation between Fas/ FasL and TNFa/TNFRI is a potential suppressive mechanism of hCII707-721-reactive iNKT cells, as supported by the use of cytotoxic mechanisms by human NKT cells against a myelomonocytic leukemia cell line, including perforin/ granzyme-B, TNFa, FAS-L, and TRAIL. ${ }^{42}$ Although 7AAD staining of cell death was not shown in the differences, it does not rule out a possibility that cell apoptosis could be involved in hCII707-721-reactive iNKT cell-mediated suppression.

Although NKT cells primarily recognize and react to glycolipids in the context of CD1 molecules, they can react to peptide antigens. ${ }^{43} \mathrm{NKT}$ cell regulation of immune homeostasis might depend on the recognition of self-antigens under stress, such as tissue damage, which causes the release of self- antigens. ${ }^{33}$ Notably, certain NKT cells react with sulfatide, a self-glycolipid in the myelin sheaths that coats and insulates nerve fibers in the CNS. ${ }^{44} \mathrm{CD} 1$-dependent activation by a-GalCer in mice induces all signature cytokines of various $T$ helper subsets, demonstrating the cytokine storm that is elicited by this stimulation. ${ }^{45}$ In contrast, the self-peptide hCII707-721 seems to be protective because of the consequent low cytokine output-except for TNF $\alpha$, which initiates its TNFRI-mediated suppression - unlike with other CD1restricted NKT cells, such as $\alpha$-GalCer-reactive cells.

In summary, we found iNKT cells to be hyporesponsive to hCII707-721 in patients with PMS, reflecting a potential state of anergy in circulating self-reactive iNKT cells in these patients. Determining how anergic iNKT cells can be activated in patients with PMS might be helpful in designing hCII707721-based therapies. Furthermore, direct clinical benefits have been obtained by stimulating or adoptively transferring NKT cells to correct defects in the NKT cell pool. ${ }^{8,9,17,21,46}$ Low production of IFN- $\gamma$, IL-4, and IL-17F by hCII707721-reactive iNKT cells is a highly favorable attribute, avoiding, for example, shifts in polarizing $\mathrm{T}$ helper subsets, which are associated with pathology in MS. ${ }^{47}$ Thus, based on our novel identification of endogenous self-antigen hCII707721-reactive iNKT cells, approaches that use hCII707-721 to expand and activate hCII707-721-reactive iNKT cells have tremendous therapeutic potential to correct the defects of NKT cells in patients with MS and prevent disease progression.

\section{Study Funding}

This work was supported by grants from the Lundbeck Foundation, Danish MS Society, Independent Research Fund Denmark-Medical and Health Sciences (DFF-M), and Foundation for Research in Neurology (to S.I.-N.). B. Carrion received a PhD fellowship from CONACYT-Mexico and the Lundbeck Foundation. M. Hadi was the recipient of a McDonald fellowship from the MSIF program.

\section{Disclosure}

The authors report no disclosures relevant to the manuscript. Go to Neurology.org/NN for full disclosures.

\section{Publication History}

Received by Neurology: Neuroimmunology \& Neuroinflammation February 4, 2021. Accepted in final form June 16, 2021.

\section{Appendix Authors}

\begin{tabular}{lll}
\hline Name & Location & Contribution \\
\hline $\begin{array}{ll}\text { Belinda } \\
\text { Carrión, MD, }\end{array}$ & $\begin{array}{l}\text { Biotech Research and } \\
\text { Innovation Centre (BRIC), }\end{array}$ & $\begin{array}{l}\text { Drafting/revision of the } \\
\text { manuscript for content, } \\
\text { PhD }\end{array}$ \\
$\begin{array}{ll}\text { University of Copenhagen, } \\
\text { including medical writing } \\
\text { for content; Major role in } \\
\end{array}$ & $\begin{array}{l}\text { the acquisition of data; } \\
\text { Study concept or design; } \\
\end{array}$ \\
& $\begin{array}{l}\text { Analysis or interpretation } \\
\text { of data }\end{array}$ \\
\end{tabular}


Appendix (continued)

\begin{tabular}{lll}
\hline Name & Location & Contribution \\
\hline $\begin{array}{ll}\text { Yawei Liu, } \\
\text { MD, PhD }\end{array}$ & $\begin{array}{l}\text { Biotech Research and } \\
\text { Innovation Centre (BRIC), } \\
\text { University of Copenhagen, } \\
\text { Denmark }\end{array}$ & $\begin{array}{l}\text { Drafting/revision of the } \\
\text { manuscript for content, } \\
\text { including medical writing } \\
\text { for content; Major role in } \\
\text { the acquisition of data; } \\
\end{array}$ \\
& $\begin{array}{l}\text { Analysis or interpretation } \\
\text { of data }\end{array}$
\end{tabular}

\begin{tabular}{lll}
\hline Mahdieh & Biotech Research and & Major role in the \\
Hadi, PhD & Innovation Centre (BRIC), & acquisition of data; \\
& $\begin{array}{l}\text { University of Copenhagen, } \\
\text { Denmark }\end{array}$ & $\begin{array}{l}\text { Analysis or interpretation } \\
\text { of data }\end{array}$
\end{tabular}

\begin{tabular}{lll}
\hline Jon & Biotech Research and & Major role in the \\
Lundstrom, & Innovation Centre (BRIC), & acquisition of data; \\
MSc & University of Copenhagen, & Analysis or interpretation \\
& Denmark
\end{tabular}

Denmark of data

\begin{tabular}{lll}
\hline $\begin{array}{l}\text { Jeppe Romme } \\
\text { Christensen, } \\
\text { MD PhD }\end{array}$ & $\begin{array}{l}\text { Danish Multiple Sclerosis } \\
\text { Center, University of } \\
\text { Copenhagen and } \\
\text { Department of Neurology, } \\
\text { Rigshospitalet, Denmark; }\end{array}$ & $\begin{array}{l}\text { Major role in the } \\
\text { acquisition of data; } \\
\text { Analysis or interpretation } \\
\text { of data }\end{array}$ \\
\hline Cecilie & $\begin{array}{l}\text { Danish Multiple Sclerosis } \\
\text { Center, University of }\end{array}$ & $\begin{array}{l}\text { Major role in the } \\
\text { acquisition of data }\end{array}$ \\
MD, PhD & $\begin{array}{l}\text { Copenhagen and } \\
\text { Department of Neurology, } \\
\text { Rigshospitalet, Denmark }\end{array}$ &
\end{tabular}

\begin{tabular}{lll}
\hline Morten & Blood Bank, Copenhagen & Major role in the \\
Hanefeld & University Hospital, Denmark & acquisition of data \\
Dziegiel, MD, & & \\
PhD &
\end{tabular}

\begin{tabular}{lll}
\hline $\begin{array}{l}\text { Per Soelberg } \\
\text { Sørensen, MD }\end{array}$ & $\begin{array}{l}\text { Danish Multiple Sclerosis } \\
\text { Center, University of } \\
\text { Copenhagen and }\end{array}$ & $\begin{array}{l}\text { Major role in the } \\
\text { acquisition of data } \\
\text { Department of Neurology, } \\
\text { Rigshospitalet, Denmark }\end{array}$
\end{tabular}

\begin{tabular}{ll}
\hline Manuel & Centre d'Esclerosi Múltiple de \\
Comabella, & Catalunya, Cemcat, Unitat de acquisition of data \\
MD, PhD & Neuroimmunologia Clínica, \\
& Hospital Universitari Vall d' \\
& Hebron (HUVH) Universitat \\
& Autònoma de Barcelona, \\
& Barcelona, Spain
\end{tabular}

\begin{tabular}{ll}
\hline Xavier & Centre d Esclerosi Múltiple de Major role in the \\
Montalban, & Catalunya, Cemcat, Unitat de acquisition of data \\
MD, PhD & Neuroimmunologia Clínica, \\
& Hospital Universitari Vall d' \\
& Hebron (HUVH) Universitat \\
& Autònoma de Barcelona, \\
& Barcelona, Spain
\end{tabular}

\begin{tabular}{lll}
\hline $\begin{array}{l}\text { Finn } \\
\text { Sellebjerg, } \\
\text { MD, PhD }\end{array}$ & $\begin{array}{l}\text { Danish Multiple Sclerosis } \\
\text { Center, University of } \\
\text { Copenhagen and } \\
\text { Department of Neurology, } \\
\text { Rigshospitalet, Denmark }\end{array}$ & $\begin{array}{l}\text { Major role in the } \\
\text { acquisition of data }\end{array}$ \\
\hline $\begin{array}{l}\text { Shohreh } \\
\text { Issazadeh- } \\
\text { Navikas, PhD }\end{array}$ & $\begin{array}{l}\text { Biotech Research and } \\
\text { Innovation Centre (BRIC), } \\
\text { University of Copenhagen, } \\
\text { Denmark }\end{array}$ & $\begin{array}{l}\text { Drafting/revision of the } \\
\text { manuscript for content, } \\
\text { including medical writing } \\
\text { for content; Study concept } \\
\text { or design; Analysis or } \\
\text { interpretation of data }\end{array}$ \\
& &
\end{tabular}

\section{References}

1. Bendelac A, Savage PB, Teyton L. The biology of NKT cells. Annu Rev Immunol. 2007;25:297-336

2. Brigl M, Brenner MB. CD1: antigen presentation and $\mathrm{T}$ cell function. Annu Rev Immunol. 2004;22:817-890.
3. Kronenberg M. Toward an understanding of NKT cell biology: progress and paradoxes. Annu Rev Immunol. 2005;23:877-900.

4. Taniguchi M, Harada M, Kojo S, Nakayama T, Wakao H. The regulatory role of Valpha14 NKT cells in innate and acquired immune response. Annu Rev Immunol. 2003;21:483-513.

5. Van Kaer L, Parekh VV, Wu L. Invariant natural killer T cells: bridging innate and adaptive immunity. Cel Tissue Res. 2011;343(1):43-55.

6. Tupin E, Kinjo Y, Kronenberg M. The unique role of natural killer $\mathrm{T}$ cells in the response to microorganisms. Nat Rev Microbiol. 2007;5(6):405-417.

7. Terabe M, Berzofsky JA. NKT cells in immunoregulation of tumor immunity: a new immunoregulatory axis. Trends Immunology. 2007;28(11):491-496.

8. Teige A, Teige I, Lavasani S, et al. CD1-dependent regulation of chronic central nervous system inflammation in experimental autoimmune encephalomyelitis. J Immunol. 2004;172(1):186-194.

9. Teige A, Bockermann R, Hasan M, Olofsson KE, Liu Y, Issazadeh-Navikas S. CD1ddependent NKT cells play a protective role in acute and chronic arthritis models by ameliorating antigen-specific Th1 responses. J Immunol. 2010;185(1):345-356.

10. Novak J, Lehuen A. Mechanism of regulation of autoimmunity by iNKT cells. Cytokine. 2011;53(3):263-270.

11. Van Kaer L, Wu L, Parekh VV. Natural killer T cells in multiple sclerosis and its animal model, experimental autoimmune encephalomyelitis. Immunology. 2015;146(1):1-10.

12. Goverman J. Autoimmune T cell responses in the central nervous system. Nat Rev Immunol. 2009;9(6):393-407.

13. Illes Z, Kondo T, Newcombe J, Oka N, Tabira T, Yamamura T. Differential expression of NK T cell V alpha 24J alpha Q invariant TCR chain in the lesions of multiple sclerosis and chronic inflammatory demyelinating polyneuropathy. J Immunol. 2000; 164(8):4375-4381.

14. van der Vliet HJ, von Blomberg BM, Nishi N, et al. Circulating V(alpha24+) Vbeta11+ NKT cell numbers are decreased in a wide variety of diseases that are characterized by autoreactive tissue damage. Clin Immunol. 2001;100(2):144-148.

15. Araki M, Kondo T, Gumperz JE, Brenner MB, Miyake S, Yamamura T. Th2 bias of CD4+ NKT cells derived from multiple sclerosis in remission. Int Immunol. 2003; 15(2):279-288.

16. Pal E, Tabira T, Kawano T, Taniguchi M, Miyake S, Yamamura T. Costimulationdependent modulation of experimental autoimmune encephalomyelitis by ligand stimulation of V alpha 14 NK T cells. J Immunol. 2001;166(1):662-668.

17. Singh AK, Wilson MT, Hong S, et al. Natural killer T cell activation protects mice against experimental autoimmune encephalomyelitis. J Exp Med. 2001;194(12):1801-1811.

18. Osman Y, Kawamura T, Naito T, et al. Activation of hepatic NKT cells and subsequent liver injury following administration of alpha-galactosylceramide. Eur J Immunol. 2000;30(7):1919-1928.

19. Ito K, Karasawa M, Kawano T, et al. Involvement of decidual Valpha14 NKT cells in abortion. Proc Natl Acad Sci U S A. 2000;97(2):740-744.

20. Whitman SC, Ramsamy TA. Participatory role of natural killer and natural killer $\mathrm{T}$ cells in atherosclerosis: lessons learned from in vivo mouse studies. Can J Physiol Pharmacol. 2006;84(1):67-75.

21. Liu Y, Teige A, Mondoc E, Ibrahim S, Holmdahl R, Issazadeh-Navikas S. Endogenous collagen peptide activation of CD1d-restricted NKT cells ameliorates tissue-specific inflammation in mice. J Clin Invest. 2011;121(1):249-264.

22. O'Keeffe J, Gately CM, Counihan T, et al. T-cells expressing natural killer (NK) receptors are altered in multiple sclerosis and responses to alpha-galactosylceramide are impaired. J Neurol Sci. 2008;275(1-2):22-28.

23. Hu H, Miao YR, Jia LH, Yu QY, Zhang Q, Guo AY. AnimalTFDB 3.0: a comprehensive resource for annotation and prediction of animal transcription factors. Nucleic Acids Res. 2019;47(D1):D33-D38.

24. Szklarczyk D, Gable AL, Lyon D, et al. STRING v11: protein-protein association networks with increased coverage, supporting functional discovery in genome-wide experimental datasets. Nucleic Acids Res. 2019;47(D1):D607-D613.

25. Lu W, Wang X, Liu J, et al. Downregulation of ARHGDIA contributes to human glioma progression through activation of Rho GTPase signaling pathway. Tumour Biol. 2016;37(12):15783-15793.

26. Manresa-Arraut A, Johansen FF, Brakebusch C, Issazadeh-Navikas S, Hasseldam H. RhoA drives T-cell activation and encephalitogenic potential in an animal model of multiple sclerosis. Front Immunol. 2018;9:1235.

27. Duggal S, Jailkhani N, Midha MK, Agrawal N, Rao KVS, Kumar A. Defining the Akt1 interactome and its role in regulating the cell cycle. Sci Rep. 2018;8(1):1303.

28. Wu L, Van Kaer L. Natural killer T cells and autoimmune disease. Curr Mol Med. 2009;9(1):4-14.

29. Gumperz JE, Miyake S, Yamamura T, Brenner MB. Functionally distinct subsets of CD1d-restricted natural killer T cells revealed by CD1d tetramer staining. J Exp Med. 2002;195(5):625-636.

30. Lee PT, Benlagha K, Teyton L, Bendelac A. Distinct functional lineages of human V(alpha)24 natural killer T cells. J Exp Med. 2002;195(5):637-641.

31. Zimmerer JM, Horne PH, Fiessinger LA, et al. Cytotoxic effector function of CD4independent, CD8(+) T cells is mediated by TNF-alpha/TNFR. Transplantation. 2012;94(11):1103-1110.

32. Swann JB, Coquet JM, Smyth MJ, Godfrey DI. CD1-restricted T cells and tumor immunity. Curr Top Microbiol Immunol. 2007;314:293-323.

33. Issazadeh-Navikas SNKT. Cell self-reactivity: evolutionary master key of immune homeostasis? J Mol Cell Biol. 2012;4(2):70-78

34. Liu Y, Carlsson R, Comabella M, et al. FoxA1 directs the lineage and immunosuppressive properties of a novel regulatory T cell population in EAE and MS. Nat Med. 2014;20(3):272-282 
35. Meyer EH, DeKruyff RH, Umetsu DT. iNKT cells in allergic disease. Curr Top Microbiol Immunol. 2007;314:269-291.

36. Vivier E, Ugolini S, Blaise D, Chabannon C, Brossay L. Targeting natural killer cells and natural killer T cells in cancer. Nat Rev Immunol. 2012;12(4):239-252.

37. Berzins SP, Ritchie DS. Natural killer T cells: drivers or passengers in preventing human disease? Nat Rev Immunol. 2014;14(7):640-646.

38. Cohen NR, Brennan PJ, Shay T, et al. Shared and distinct transcriptional programs underlie the hybrid nature of iNKT cells. Nat Immunol. 2013;14(1):90-99.

39. Kawano T, Cui J, Koezuka Y, et al. Natural killer-like nonspecific tumor cell lysis mediated by specific ligand-activated Valpha14 NKT cells. Proc Natl Acad Sci U S A. 1998;95(10):5690-5693.

40. Arase N, Arase H, Good RA, Onoe K. Contribution of host radioresistant T cells to the clonal elimination of minor lymphocyte stimulatory-1a reactive $\mathrm{T}$ cells in mouse bone marrow chimeras. Cell Immunol. 1994;156(1):13-23.

41. Moroda $\mathrm{T}$, Iiai $\mathrm{T}$, Suzuki $\mathrm{S}$, et al. Autologous killing by a population of intermediate T-cell receptor cells and its NK1.1+ and NK1.1- subsets, using Fas ligand/Fas molecules. Immunology. 1997;91(2):219-226.

42. Metelitsa LS, Weinberg KI, Emanuel PD, Seeger RC. Expression of CD1d by myelomonocytic leukemias provides a target for cytotoxic NKT cells. Leukemia. 2003; 17(6):1068-1077.

43. Castano AR, Tangri S, Miller JE, et al. Peptide binding and presentation by mouse CD1. Science. 1995;269(5221):223-226.

44. Jahng A, Maricic I, Aguilera C, Cardell S, Halder RC, Kumar V. Prevention of autoimmunity by targeting a distinct, noninvariant $\mathrm{CD} 1 \mathrm{~d}$-reactive $\mathrm{T}$ cell population reactive to sulfatide. J Exp Med. 2004;199(7):947-957.

45. Niemeyer M, Darmoise A, Mollenkopf HJ, et al. Natural killer T-cell characterization through gene expression profiling: an account of versatility bridging $\mathrm{T}$ helper type 1 (Th1), Th2 and Th17 immune responses. Immunology. 2008;123(1) 45-56.

46. Jahng AW, Maricic I, Pedersen B, et al. Activation of natural killer T cells potentiates or prevents experimental autoimmune encephalomyelitis. J Exp Med. 2001;194(12): 1789-1799.

47. Hirahara K, Nakayama T. CD4+ T-cell subsets in inflammatory diseases: beyond the Th1/Th2 paradigm. Int Immunol. 2016;28(4):163-171.

48. Lublin FD, Reingold SC. Defining the clinical course of multiple sclerosis: results of an international survey. National Multiple Sclerosis Society (USA) Advisory Committee on Clinical Trials of New Agents in Multiple Sclerosis. Neurology. 1996;46(4): 907-911.

49. Picelli S, Faridani OR, Bjorklund AK, Winberg G, Sagasser S, Sandberg R. Full-length RNA-seq from single cells using Smart-seq2. Nat Protoc. 2014;9(1):171-181.

50. Vitting-Seerup K, Sandelin A. The landscape of isoform Switches in human Cancers. Mol Cancer Res. 2017;15(9):1206-1220.

51. Yu G, He QY. ReactomePA: an R/Bioconductor package for reactome pathway analysis and visualization. Mol Biosyst. 2016;12(2):477-479.

52. Wu D, Smyth GK. Camera: a competitive gene set test accounting for inter-gene correlation. Nucleic Acids Res. 2012;40(17):e133.

53. Subramanian A, Tamayo P, Mootha VK, et al. Gene set enrichment analysis: knowledge-based approach for interpreting genome-wide expression profiles. Proc Natl Acad Sci U S A. 2005;102(43):15545-15550.

54. Liberzon A, Subramanian A, Pinchback R, Thorvaldsdottir H, Tamayo P, Mesirov JP. Molecular signatures database (MSigDB) 3.0. Bioinformatics. 2011;27(12): 1739-1740.

55. Korotkevich T, Sukhov V, Budin N, et al. Fast gene set enrichment analysis. BioRxive. 2019. doi: $10.1101 / 060012$. 


\section{Neurology \\ Neuroimmunology \& Neuroinflammation}

\section{Transcriptome and Function of Novel Immunosuppressive Autoreactive Invariant Natural Killer T Cells That Are Absent in Progressive Multiple Sclerosis \\ Belinda Carrión, Yawei Liu, Mahdieh Hadi, et al. \\ Neurol Neuroimmunol Neuroinflamm 2021;8; \\ DOI 10.1212/NXI.0000000000001065}

This information is current as of August 12, 2021

Updated Information \&

Services

References

Subspecialty Collections

Permissions \& Licensing

Reprints including high resolution figures, can be found at:

http://nn.neurology.org/content/8/6/e1065.full.html

This article cites 55 articles, 15 of which you can access for free at: http://nn.neurology.org/content/8/6/e1065.full.html\#\#ref-list-1

This article, along with others on similar topics, appears in the following collection(s):

All Immunology

http://nn.neurology.org//cgi/collection/all_immunology

Autoimmune diseases

http://nn.neurology.org//cgi/collection/autoimmune_diseases

Multiple sclerosis

http://nn.neurology.org//cgi/collection/multiple_sclerosis

Information about reproducing this article in parts (figures,tables) or in its entirety can be found online at:

http://nn.neurology.org/misc/about.xhtml\#permissions

Information about ordering reprints can be found online:

http://nn.neurology.org/misc/addir.xhtml\#reprintsus

Neurol Neuroimmunol Neuroinflamm is an official journal of the American Academy of Neurology.

Published since April 2014, it is an open-access, online-only, continuous publication journal. Copyright

Copyright (C) 2021 The Author(s). Published by Wolters Kluwer Health, Inc. on behalf of the American

Academy of Neurology.. All rights reserved. Online ISSN: 2332-7812.

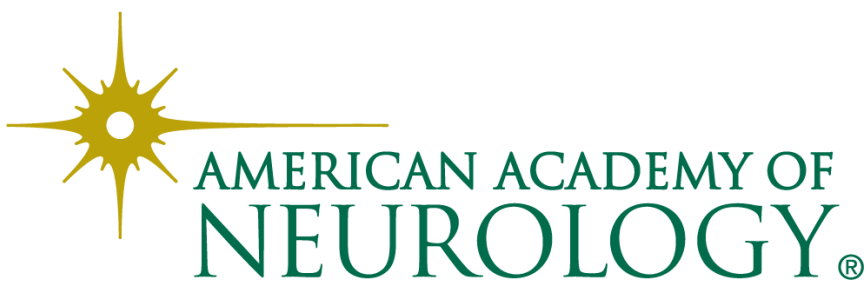

